\author{
ARAŞTIRMA MAKALESI

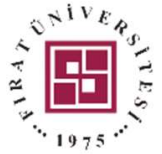 \\ Frrat Üniversitesi Sosyal Bilimler Dergisi \\ The Journal of International Social Sciences \\ Cilt: 29, Say1: 1, Sayfa: 381-398, OCAK - 2019 \\ Makale Gönderme Tarihi: 17.10.2018 Kabul Tarihi: 02.01.2019

\section{J. MACDONALD KINNEIR'E GÖRE KIBRIS: MAĞUSA, LARNAKA, LEFKOŞA} \\ To J. Maddonald Kınneır Cyprus: Famagusta, Larnaca, Nicosia \\ Ayşegül KUŞ ${ }^{1}$ \\ ÖZ
}

\begin{abstract}
Kıbrıs, Akdeniz'in üç büyük adasından birisidir. Jeo-stratejik konumu gereği erken dönemlerden beri, insanlı̆̆ın ilgisini çekmiş ve önemli bir yerleşim merkezi olmuştur. Ada, her şeyden önce, eski ve büyük bir uygarlık beşiği olan Akdeniz havzasına hâkim bir konumdadır ve bu özel durumu nedeniyle, geçmişten günümüze bu bölgelerde hâkimiyet kurmak isteyen pek çok devletin ilgi odağı olmuştur. Nitekim tarihsel süreç içerisinde Anadolu, Suriye, Kuzey Afrika ve Avrupa'da ortaya çıkan hemen her devlet, Kıbrıs adası üzerinde hâkimiyet tesis etmeye çalışmış; bir ada olarak Kıbrıs, pek çok istilalara ve fetihlere sahne olmuştur. Osmanlılar da, Akdeniz üzerindeki hâkimiyet alanını genişletmek ve garanti altına almak için, 1571'de adayı fethetmişler ve kendi topraklarının bir parçası haline getirmişlerdir. Böylelikle ada, Türk-İslam uygarlığının önemli merkezlerinden birisi haline gelmiş̧ir. Tarih öncesi dönemlerden itibaren çok sayıda seyyahın uğrak yerlerinden birisi olan Kıbrıs, Osmanlı topraklarına gelen kimi batılı seyyahların da dikkatini çekmiş̧tir. Bu seyyahlar, ada hakkında gözlemlerini aktarmışlar, adanın tarihsel ve sosyo-kültürel gelişimini anlamamıza olanak sağlayacak önemli bilgiler sunmuşlardır. Ada hakkında gözlemlerini aktaran önemli seyyahlardan birisi de, 19. yüzyılın ilk yarısında Kıbrıs'ta bulunan İngiliz seyyah J. McDonald Kinneir'dir. İște bu çalışmanın amacı, onun gezi notlarından yola çıarak adanın o dönem içinde bulunduğu fiziki, coğrafi, idari, siyasi ve sosyo-kültürel durumuna ışık tutmak ve adanın tarihine kimi katkılar sağlamaktır.
\end{abstract}

Anahtar Sözcükler: Kıbrıs, Kinneir, fiziki yapı, idari ve siyasi yapı, sosyo-kültürel yapı.

\title{
ABSTRACT
}

Cyprus is one of the three islands of the Mediterranean. Due to its geo-strategic position it has drawn the attention of the people and has become an important settlement since the early periods. Firstly, the island is on the location which dominates the Mediterranean region and due to this fact from past to present it has become the focus of interest of many different states which aimed to establish domination. In fact, throughout the course of history nearly every state which emerged in Anatolia, Syria, North Africa, and Europe tried to establish domination over Cyprus and as an island Cyprus was exposed to many invasions and conquests. The Ottomans, being eager to expand and guarantee their domination over the island, conquered the island in 1571 and made it the part of their homeland. Thus the island became an important center of the Turkish-Islamic culture. Cyprus, one of the most frequently visited places by travelers from the ancient times on also drew the attention of some of the Western travelers having viisted the Ottoman lands. Those travelers narrated their own observations regarding the island, and they provided important information which can help us to understand the historical and socio-cultural development of the island. One of these travellers having narrated his own observations related to the island is J. McDonald Kinneir, who visited the island in the first half of the 19th century. Making use of his travelogues, the aim of this study is to try to enlighten the physical, geographic, administrative, political and socio-cultural structure of the island and make some contributions to the history of thei sland.

KeyWords: Cyprus, physical structure, administtative and political structure, socio-cultural structure, Kinneir.

\section{Giriş}

Kıbrıs, tarihin en eski dönemlerinden itibaren jeo-stratejik bakımdan sahip olduğu önemi günümüze kadar korumuştur. Bu bağlamda, Kıbrıs adası, Akdeniz'de özellikle de Doğu Akdeniz'de bulunduğu bu özel konum itibariyle, tarih boyunca birçok medeniyetin, milletin ve devletin ilgisini

\footnotetext{
${ }^{1}$ Dr. Öğr. Gör., Ondokuz Mayıs Üniversitesi, Eğitim Fakültesi, SAMSUN e-posta: aysegulk@omu.edu.tr
} 
çekmiştir. $^{2}$ Örneğin, Anadolu, Suriye, Kuzey Afrika ve Avrupa'da ortaya çıkan devletler belirli dönemlerde ada üzerinde hâkimiyet kurmuşlardır. Ancak adayı ele geçiren güçler burayı anavatanlarının bir parçası haline getirmemişlerdir. Bu nedenle de adadaki hâkimiyetleri, siyasi ömürleri ile sınırlı kalmıştır. Her ne kadar söz konusu güçler Kıbrıs'ı anavatanlarının bir parçası haline getirmemişlerse de adayı terk etmek zorunda kaldıklarında, orada kendi kültür ve uygarlıklarından birtakım izler bırakmışlardır. Bu durumun, adanın bugün sahip olduğu kültürel zenginlik üzerinde önemli bir etkisinin olduğunu belirtmek gerekir. Türklerin Kıbrıs'a yönelik ilgileri 1207 yılında Selçuklu Sultanı Gıyasettin Keyhüsrev'in Antalya'yı fethetmesinden sonra başlamıştır. 13. yüzyılın başında Selçuklu sultanları ile Kıbrıs kralları arasında dostluk ahidnameleri ve beraberinde birtakım ticari ilişkiler görülmektedir. Kıbrıs adasının Osmanlılar tarafından ele geçirilmesi ise II. Selim zamanında 1571 yılında olmuştur. Osmanlılar, adada daha önce hâkimiyet kuran güçlerden farklı olarak, burayı anavatanlarının bir parçası olarak görmüşlerdir. ${ }^{3}$ Osmanlı Devleti, hemen her yerde olduğu gibi, burada da daha başlangıçtan itibaren klasik "fetih metodu" doğrultusunda hareket etmiştir. Bu nedenle, önemli bir kısmı Bizans ve Frank dönemlerinden beri devam eden pek çok unsuru bünyesinde barındıran Venedik idaresinden memnun olmayan ada halkını kendisine bağlamak ve idarî teşkilâtını kurmak yönünde yoğun bir faaliyete girmiştir. Kıbrıs tarihine dair kaynaklarda, 1570 yılının sonlarına doğru Osmanlıların daha fetih tamamlanmadan önce adayı tipik bir Osmanlı eyaletine dönüştürmek için birtakım girişimlerde bulunduklarını göstermektedir. Nitekim Serdar Lala Mustafa Paşanın ruznamçe defterinden edinilen bilgilere göre Lefkoşa'nın fethedildiği gün Kıbrıs bir beylerbeylik haline getirilmiş ve Avlonya sancakbeyi Muzaffer Paşa'ya tevcih edilmiştir. 1 Ağustos 1571 'de ise, Alâiye, Sis, Tarsus ve İç-il sancaklarının da adaya bağlanmasıyla, idari bakımdan Anadolu ile bütünleşmiştir. ${ }^{4}$ Bununla birlikte, fetih metodu doğrultusunda gerçekleştirilen bütün bu işlemlerle, adada Osmanlı düzeninin tesis edilmesiyle birlikte gündeme gelen ikinci önemli mesele, Kıbrı'ın iskânı olmuştur. Kıbrıs fetihten önce 200.000 'e yakın nüfusu bulunan ve fethi müteakiben yapılan ilk tahrirde 905 meskûn köye karş1lık 76 "hâlî-harâb" köy ile birlikte, büyük çoğunluğu Lefkoşa, Limasol, Baf, Girne ve Mağusa kalelerinde toplanmış bulunan 3.779 Osmanlı askeri ve muayyen sayıda idarecisini bünyesinde barındıran bir yerleşim birimiydi. Adanın fetihten sonra Türk iskânıyla şenlendirilmesi ve mamur hâle getirilmesi için büyük nüfus kitlelerine ihtiyaç duyulmuştur. Bu ise daha önce fethedilen bölgelerde de olduğu gibi, büyük ölçüde "bir iskân ve kolonizasyon metodu" olarak sürgün usulünün uygulanması ile gerçekleşmiştir ${ }^{5}$. Bu iskân genelde kendi rızalarıyla gidenleri kapsadığı gibi, iskâna

\footnotetext{
${ }^{2}$ Ali Efdal Özkul, “Osmanlı İdaresinde Kıbrıs’ta Ermeni Toplumu ve Faaliyetleri”, Yeni Türkiye, S.60, 2014, s.1.

${ }^{3}$ Celal Erdönmez, Şer'iyye Sicillerine Göre Kıbrıs'ta Toplum Yapısı (1839-1856), SDÜ Sosyal Bilimler Enstitüsü Tarih Anabilim Dalı, Yayınlanmamış Doktora Tezi, Isparta 2004, s. 1v; Gülay Öğün, "Kıbrıs'ta İslam Hâkimiyeti ve Selçuklular Zamanında Kıbrıs İle Ticaret İlişkileri", Dünden Bugüne Kıbrıs Meselesi, (yay. haz.). Ali Ahmetbeyoğlu-Erhan Afyoncu, İstanbul 2001, s. 1; Abdulkadir Yuvalı, "Selçuklular Döneminde Kıbrıs'ın Anadolu İle Siyasi ve Ticari ilişkileri", Kıbrıs'ın Dünü-Bugünü Uluslararası Sempozyumu, Ankara 1993, s.37

${ }^{4}$ M. Akif Erdoğru, "Kıbrıs'ın Türkler Tarafindan Fethi ve İlk İskân Teşebbüsü", Kıbrıs'ın Dünü-Bugünü Uluslararası Seтровуити, Ankara: KKTC Doğu Akdeniz Üniversitesi ve Van 100. Y1l Üniversitesi Rektörlükleri Yayınları, 1993, s.4546; Kemal Çiçek, "Kıbrıs”, D.İ.A., C. 25, 2002, s. 375.

${ }^{5}$ Turan Gökçe, “1572 yılında İç-İl Sancağından sürülüp Kıbrıs’ta İskân Edilen Aileler”, Türk Dünyası İncelemeleri Dergisi, İzmir 1997,s.2. Kıbrıs'ta hâkimiyetin sürekliliğinin sağlanması, toprağın işlenerek ekonomiye kazandırılması ve ticaretin canlandırılabilmesi için Türk nüfus yeterli değildi. Bu durumu gören Kıbrıs Beylerbeyi Sinan Paşa Sultan II. Selim'e bir mektup göndererek Kıbrıs'ın arazi, nüfus ve gelir durumu hakkında bilgiler vermiş, Venediklilerden boşalan arazinin işlenemediğini, adanın kalkınması için yeterli sayıda sanatkâr bulunmadığını bildirmiştir. Bu mektup üzerine Sultan II. Selim, Kıbrıs'ın kalkınması, zenginleşmesi ve Kıbrıs'taki Türk nüfusun takviyesi için 22 Eylül 1572 tarihli bir hüküm ile Kıbrıs'a Türk ailelerin iskânını emretmiştir. Osmanlı Devleti, Kıbrıs'ın nüfusunu takviye etmek amacıyla daha sonraki y1llarda da adaya Türk iskânını sürdürmüştür bkz.M. Tevfik Tarkan, Kıbrıs (Genel Çizgileriyle),Ankara: Atatürk Üniversitesi Edebiyat Fakültesi Yayınları 1975, s.57; Bener Hakkı Hakeri, Başlangıçtan 1878'e dek Kıbrıs Tarihi, Lefkoşa: Milli Eğitim ve Kültür Bakanlığı Yayını 1993, s. 238; Cengiz Orhonlu, "Osmanlı Türklerinin Kıbrıs Adasına Yerleşmesi (1570-1580), Milletlerarası Birinci Kıbrıs Tetkikleri Kongresi (14-19 Nisan 1969), Türk Heyeti Tebliğleri, Ankara: Türk Kültürünü Araştırma Enstitüsü Yayınları 1971, s.94; Cengiz Orhonlu, Osmanlı İdaresinde Kıbrıs (Nüfusu-Arazi Dağılımı ve Türk Vakıfları), Ankara: Devlet Arşivleri Genel Müdürlüğü Osmanlı Arşivi Daire Başkanlığı Yayınları 2000, s.18; Osmanlı Devlet'inin Kıbrıs'ta kurduğu idari düzen hakkında bkz. Ali Efdal Özkul, Kıbrıs 'ın Sosyo- Ekonomik Tarihi (1726-
} 
tabi tutulan yöre ahalisinden her on hâneden bir hâne olmak üzere tespit edilen miktarın "sürgün" denilen usulle nakli şeklinde de olmuştur. İskâna tabi tutulanlar belli bir süre vergilerden muaf tutulmak ve yerleştikleri yerler kendilerine mülk olarak verilmek gibi şartlarla nakledilmiştir. Kıbrıs'ın fethinden sonra da buna benzer bir yol izlenmiştir. Söz gelimi naklin gerçekleşmesi ve gidecekleri teşvik etmek amacıyla adanın ikliminin güzelliğinden, topraklarının her türlü tarıma elverişli olduğundan bahsedilerek birtakım propagandalar yapılmıştır. ${ }^{6}$

Ada'nın Türkler tarafından fethi, 1570 yılının baharında başlamış ve sefer en son Mağusa kalesinin alınmasıyla 1 Ağustos 1571 'de tamamlanmıştır. Bu tarihten itibaren Türk iskânına açılan Kıbrıs'ta 308 senelik bir Osmanlı hâkimiyeti başlamıştır. ${ }^{7}$ Kıbrıs'ta meydana gelen Osmanlı Venedik Savaşları'ndan dolayı Kıbrıs halkının bir bölümü ada dışına kaçmış bir bölümü de dağlara sığınmıştı. Bu durum karşısında Osmanlı yönetimi, Kıbrıs halkının geri dönmeleri için de gayret sarf etmiştir. ${ }^{8}$ Gerek ada halkının geri dönmesi gerekse Osmanlıların Anadolu'dan adaya gönderdikleri Türkler Türk- Rum yerleşmelerini meydana getirmiştir. Fakat adada nüfus düzenlemesi yapılırken Müslim ve gayrimüslim ayrımı yapılmamıştır. ${ }^{9}$ Sözgelimi, Osmanlı Devleti'nin adayı fethini müteakip Anadolu'nun çeşitli yerlerinden yeterli sayıda Müslüman Türk nüfus, Kıbrıs'a gönderilerek burada iskân edilmiştir. Adaya iskân edilen Türk nüfus burada Osmanlı Devleti'nin diğer eyaletlerinde olduğu gibi Osmanlı toplum örneğini olușturmuşlardır. Osmanlı Devleti tarafından Kıbrıs'a Türk nüfusu yerleştirme politikası, 18. yüzyıla kadar belli aralıklarla devam etmiştir. İzlenen bu siyaset, Osmanlı döneminde Kıbrıs adası ile demografik bağlantıların canlı tutulduğunu göstermesi bakımından önemlidir. ${ }^{10}$ Ayrıca Kıbrıs, fethedildikten sonra farklı idari statülere tabi olarak 308 yıl Osmanlı hâkimiyeti altında kalmıştır. ${ }^{11}$

Kıbrıs adasına olan ilgi salt devletler düzeyinde hâkimiyet kurma isteğiyle sınırlı kalmamış, aynı şekilde, çeşitli amaçlarla seyyah ve araştırmacılar da adaya ilgi göstermişlerdir. Bu doğrultuda, gerek Osmanlı hâkimiyeti öncesi gerekse Osmanlı hâkimiyeti döneminde adaya pek çok seyyah ve araştırmacının geldiğini kaydetmek gerekir. Tarihsel süreç içerisinde adaya yollarını düşüren Pococke, Bruyn, Tavernier, Beavau, Pietrodella Valle, Drummond, Monti, Clarke, Light, Turner, Carne, Ross, Gaudry gibi seyyah ve araştırmacılar burada bulundukları zaman zarfında kendilerine ilginç gelen konuları gezi notlarında kayıt altına almışlardır. Osmanlı coğrafyasına gelen bu seyyah ve araştırmacıların, gözlem ve incelemelerini konu alan çok sayıda seyahatname bulunmaktadır. Kıbrıs'a 19. yüzyılın ilk yarısında gelen bu seyyahlardan birisi de İngiliz asıllı olan John Mcdonald Kinneir'dir. ${ }^{12}$ Gezgin seyahatleri esnasında kaleme aldığı gözlem ve incelemelerini Journey Through Asia Minor, Armenia and Koordistan in the Years 1813 and 1814 adl eserinde bir araya getirmiştir. Anadolu'da pek çok yeri gezen seyyah aynı zamanda Kıbrıs'a da gitmiştir. Kinneir'in Kıbrıs adasında bulunduğu ve adanın kimi şehirlerinin fiziki, siyasi, idari, sosyo-ekonomik yaşamına dair önemli bilgiler verdiği görülmektedir. İşte bu çalışmada, Kinneir'in Kıbrıs’ta kaldığı süre zarfında kayıt altına aldığı gözlem ve izlenimlerinden yola çıkılarak,19. yüzyılın ilk yarısında hem adanın

1750), İstanbul: Dipnot Yayınevi 2010, ss.49-96; Yusuf Halaçoğlu, "Osmanlı Döneminde Kıbrıs'ta İskân Politikası", Dünden Bugüne Kıbrıs Meselesi, (yay. haz.) Ali Ahmetbeyoğlu-Erhan Afyoncu), İstanbul: TATAV Yayınları 2001, s.43.

6 Yusuf Sarınay (ed.), Osmanlı idaresinde Kıbrıs: Nüfusu-Arazi Dağılımı ve Türk Vakıfları, Ankara: T.C. Başbakanlık Devlet Arşivleri Genel Müdürlüğü, Osmanlı Arşivi Daire Başkanlığı 2000, s. 53.

${ }^{7}$ İdris Bostan, "Kıbrıs Seferi Günlüğü ve Osmanlı Donanmasının Sefer Güzergâhı", Dünden Bugüne Kıbrıs Meselesi, ss.11-30.

${ }^{8}$ Kemal Çiçek, "Osmanlılar Zamanında Kıbrıs" Tarih ve Toplum, XXIII/136, İzmir, 1995, s.92

${ }^{9}$ Feridun Emecen, Kıbrıs'ta İlk Osmanlı İdari Yapılanması, "Dünden Bugüne Kıbrıs meselesi”, İstanbul: Tarih ve Tabiat Vakfi 2001, s.50

${ }^{10}$ Erdönmez, a.g.t., s.1v.

${ }^{11}$ Orhonlu, a.g.e., s.19-20

${ }^{12}$ Kinneir yaşamının büyük bir kısmını East India Company’nin askeri ve diplomatik hizmetinde geçirmiş olan albay gezgin ve diplomattır. 1808 ve 1814 yılları arasında Anadolu ve İran 'a bazı seyahatlerde bulunmuştur. Aynı zamanda İngiltere ve İran arasındaki ilişkilerde önemli rolleri olmuştur. Kinneir'in seyahatlerindeki amacı Anadolu coğrafyası hakkında kimi bilgiler edinmek ve olası bir Hindistan istilası hakkında takip edilecek yolları keşfetmekti bkz. Özgür Yılmaz, Batılı Seyyahlara Göre Trabzon (1808-1878), Karadeniz Teknik Üniversitesi, Sosyal Bilimler Enstitüsü Tarih Ana bilim Dalı, Basılmamış Yüksek Lisans Tezi, Trabzon 2006, s.11. 


\section{F.Ü. Sosyal Bilimler Dergisi 2019-29/1}

içinde bulunduğu genel yapı hem de Mağusa, Larnaka ve Lefkoşa şehirlerinin idari, fiziki, sosyoekonomik yönleri doküman inceleme yöntemi ile irdelenecektir. Böylelikle hem genel olarak adanın hem de özel olarak söz konusu şehirlerin 19. yüzyılın ilk yarısındaki tarihinin aydınlatılmasına katk1 sağlanmış olunacaktır.

\section{Kıbrıs Adasında İdari Yapı}

Kinneir'in Kıbrıs adasında dikkatini çeken ilk husus, adanın idarî-siyasî yapısıdır. Ona göre, ada doğru yönetilmemektedir. Yine onun ifadesiyle, Türkler hiçbir şeyi doğru yönetememektedirler. Zira Türkler, yönetim anlayışı bakımından zayıftırlar. Nitekim seyyaha göre, Kapudan Paşa (Kaptan-ı Derya) tarafindan her yıl adaya gönderilen yöneticinin (muhassıl), uyguladığı zorbalığa dayalı yönetim anlayışından sadece Hıristiyanlar değil aynı zamanda Müslümanlar da mustariptir. Buna ek olarak, özellikle Hıristiyanlar, gerek Türk yönetiminin gerekse açgözlü ve tembel olan Hıristiyan din adamlarının kimi taleplerini karşılamaya zorlanmakta ve bu nedenle ekonomik bakımdan ezilmektedirler. ${ }^{13}$ Kinneir'in adanın yönetimi hakkında verdiği bilgiler nispeten doğrudur; çünkü adada 18. yüzyılın başlarında vergi toplama imtiyazını elde eden ağalar arasında baş gösteren çekişmeler nedeniyle, adanın Kaptan-ı Derya'ya bağlı bir mütesellim tarafından yönetilmesinin otorite boşluğu yarattığı düşünülerek, adanın doğrudan veziriazama has olarak verildiği bilinmektedir. Bundan sonra adayı veziriazam adına bir muhassıl yönetmeye başlamıştır. ${ }^{14}$ Ancak 1785 'te yapılan yeni bir düzenlemeyle ada veziriazamın hassı olmaktan çıkarılıp Cezayir-i Bahr-i Sefid Beylerbeyi de olan Kaptan Paşa'nın teklifi ve Divan-1 Hümayunun tayini ile göreve gelecek bir muhassılın idaresine verilmiştir. Kısaca inisiyatif, Kaptan Paşa'ya geçmiştir. ${ }^{15}$ Bununla birlikte Kinneir, adada yaşayan Rumları idari bakımdan bir başpiskopos ve merkezden atanan Dragomanın (saray tercümanı) temsil ettiğini, bunların ise adada devlet adına vergi toplayan mütesellime karşı sorumlu olduklarını sözlerine ekler. ${ }^{16}$ İşte Kinneir'in şikâyet ettiği ve Hiristiyanları ezdiğini söylediği yapının bu olduğu ileri sürülebilir. Ancak seyyahın Türklere ve onların yönetim anlayışını yönelik sert eleştirilerinin genelleştiren ve ötekileştiren bir üslup taşıdığını belirtmek gerekir. Zira Osmanlı topraklarına 19. yüzyılda ziyaret eden seyyahların ekseriyetinin Kinneir gibi Osmanlıdaki idari yapıya ve yönetim anlayışına yönelik kimi olumsuz eleştirel yönelttikleri ancak bu seyyahlardan bazılarının iyi örnekler de sunarak daha nesnel ve sağlıklı değerlendirmeler yaptıkları görülmektedir. ${ }^{17}$

Bilindiği gibi, Osmanlı Devleti adanın fethini tamamladıktan sonra çoğunluğu Ortodoks Rum olan yerli halkı, doğrudan yönetime katmak için dini cemaatlere özerk bir şekilde kendilerini yönetme hakkı tanımıştır. Bu doğrultuda, daha önce Latinler tarafından Katolik kilisesinin egemenliği altına sokulan Kıbrıs Rum Ortodoks kilisesi, başpiskoposluk olarak yeniden açılmış, Kıbrıs’taki Rum halkının doğal temsilcisi olan Ortodoks kilisesinin eskiden sahip olduğu bazı ayrıcalıklar tekrar tanınmış ve adadaki diğer kiliselerle aynı statüye kavuşturulmuştur. Öte yandan, başpiskopos yönetim nezdinde yerli Rum halkının ruhani lideri ve siyasi temsilcisi olarak tayin edilmiştir. Böylece Rum Ortodoks cemaati adli, hukuki ve mali işlerini temsil yetkisini ruhbanlar tarafından seçilen başpiskopos ve onun gösterdiği adaylar arasından seçilen dragoman (saray

\footnotetext{
${ }^{13}$ Kinneir, a.g.e., s.181.

${ }^{14}$ Kemal Çiçek, "Kıbrıs", TDV İslam Ansiklopedisi, C.25. 2002 s.375. Osmanlı Devleti'nin adayı ele geçirmesinden sonra Kıbrıs ayrı bir beylerbeylik olarak yapılandırılmış ve 9 Ekim 1571'de Anadolu'dan Alaiye, Karaman'dan İç-il, Zülkadir'den Sis ve Halep'ten Tarsus sancakları buraya bağlanmıştı. Lefkoşa, Beylerbeyliğin Paşa Sancağı, Mağusa, Girne ve Baf kazaları ise sancağa çevrilerek toplam 8 sancaktan oluşan Kıbrıs Beylerbeyliği oluşturuldu. Bununla birlikte, adada idari, askeri, mali, hukuki ve emniyet sağlamakla üzere bazı müesseseler de oluşturuldu bkz. Çevikel, a.g.m., s.93.

${ }^{15}$ Nuri Çevikel, Kıbrıs'ta Osmanlı Mirası (1571-1960), İstanbul: 47 Numara Yayıncılık 2006a, s.167-168.

${ }^{16}$ Kinneir, a.g.e., s.181-182.

${ }^{17} \mathrm{Bu}$ konuda bkz. Henry Fanshawe Tozer, Turkish Armenia and Eastern Asia Minor, London: Longman, Green and Co 1881, s.42; Fred Burnaby, On Horseback Through Asia Minor, Vol.I, London: S. Low, Marston, Searle, \&Rivington 1877, s.243.
} 
tercümanı) vasıtasıyla kullanmaktaydı. ${ }^{18}$ Ancak seyyahın verdiği bilgilere bakılırsa, zaman içerisinde adada idari bakımdan çeşitli sebeplere bağlı olarak yönetim anlayışında bazı sorunların ortaya çıktığı ve bu sorunların adada yaşayan halkları olumsuz yönde etkilediği anlaşılmaktadır. Kinneir'in adada yaşayan Hıristiyan halkın Müslümanlara nazaran daha fazla ezildiğini vurgulamas $1,{ }^{19} \mathrm{H}$ tristiyanlara özgü olan piskoposluk yönetiminden kaynaklandığı söylenebilir. Ayrıca ada üzerine yaptığı çalışmalarıyla bilinen Özkul da gerek Osmanlı Devletinin temsilcisi olan resmi görevlilerin gerekse Ortodoks gayrimüslim halkın vekilleri ve temsilcileri olan piskoposların ve saray tercümanlarının kimi uygunsuz tutum ve davranışlarının adanın nüfusunu olumsuz yönde etkileyen faktörlerden biri olduğunu söyler. ${ }^{20}$

\section{2-Kıbrıs Adasının Sosyo- Ekonomik Yapısı}

Kinneir, adanın genel ekonomik yaşamını da gözler önüne serer. Kuşkusuz ekonomik yaşam deyince aklına ilk gelen şeyler, adada üretilen meyveler ile onların işlenmesiyle oluşturulmuş mamul ürünlerdir. $\mathrm{O}$, adanın meyvesi, şarabı, zeytinyağı ve ipeği ile ün yaptığını söylemekte; portakallarının Mora'da yetişenler kadar lezzetli olduğunu belirtmektedir. Adada kırmızı ve beyaz olmak üzere iki çeşit şarap olduğunu; bu şarapların İngiltere pazarı için Levant'da üretildiğini söyler. ${ }^{21}$ Buna paralel olarak, 17. yüzyılda adada bulunan Fransız asıllı seyyah Tavernier de adada şarap üretiminin oldukça fazla olduğunu ve üretilen şarabın komşu ülkelere ve özellikle de belli başlı ticaret merkezlerine gönderildiğini aktarır. ${ }^{22}$ Seyyahın da belirttiği gibi, adanın güneyinde, meşhur Kıbrıs şarabının üretildiği üzümlerin yetiştirildiği bağlar geniş bir alanı kaplamaktadır. Ovalarda, dağ ve tepelerde, alçak ve düz kısımlarda ise, genellikle tahıl ekilir. Kıyılara yakın kısımlarda, özellikle köy ve kasabalarda bol miktarda narenciye bahçeleri bulunur. Buna ek olarak, nar, limon, ceviz, harnup, şeftali, elma ve armut en çok yetiştirilen meyveler arasında yer almaktadır. ${ }^{23}$ Seyyah ayrıca adanın ipeği ile de bilindiğini ve ipeğin beyaz ve sarı olmak üzere iki çeşit olduğu bilgisini verir. Fakat genellikle sarı ipeğin daha fazla tercih edildiğinin altını çizer. ${ }^{24}$ Kıbrıs adasında sarı ve beyaz olmak üzere iki çeşit ipek üretildiği diğer kaynaklarca da doğrulanmaktadır. Sarı ipek, yabani dut ağaçlarından beslenen ipekböceği cinsinden elde edilmektedir. Beyaz ipek ise özel yetiştirilmiş dut ağaçlarından beslenen ipek böceklerinden üretilmektedir. ${ }^{25}$ Ayrıca Özkul, Osmanlı döneminde Kıbrıs'ın önemli geçim kaynaklarından birinin ipek üretimi olduğunu ve Sicillerde geçen Kıbrıs'taki bahçelerin çoğunun dut bahçesi olması ve bazı kayıtlarda böcek hasırı, böcek evi, ipek dolabı, vb. gibi terimlerin geçmesinin, adada ipek böcekçiliğinin yoğun olarak yapıldığını gösterdiğini belirtir. ${ }^{26}$ Kıbrıs'ta en kaliteli sarı ipek Baf, beyaz ipek ise Değirmenlik bölgesinden elde edilmektedir. ${ }^{27} 18$. yüzyılda adada üretilen ipek, pamuktan sonra en önemli ikinci ticari ürün olarak karşımıza çıkmakta ve çeşitli ülkelere pazarlanmaktadır. Beyaz ipeğin en fazla Avrupa' da tercih edildiği anlaşılmaktadır. Ancak İngiltere, Hollanda ve Fransa'ya gidenler dışında, gemilerde sarı ve sülfür ipek de

\footnotetext{
${ }^{18}$ Çiçek "Kıbrıs", s.375. Rumlar arasında çok önemli bir mevki elde eten bu iki görevli zaman içinde statülerinin ve imtiyazlarının genişletilmesiyle valiyi bile gölgede bırakacak derecede nüfuz kazandı. Özellikle 1670 yılı başlarında Divan1 Hümayun, başpiskoposluğu Hıristiyan reayanın yegâne temsilcisi konumuna yükselterek Hıristiyan reayadan toplanan vergileri tayin ve tahsilâtla yükümlü kıldı bkz. Çiçek, "Kıbrıs", s.375; Özkul, a.g.e., s.97.

${ }^{19}$ Kinneir, a.g.e., s. 181.

20 Özkul, a.g.e., s. 197.

${ }^{21}$ Kinneir, a.g.e., s.182.

${ }^{22}$ Tavernier Seyahatnamesi, (çev.), Teoman Tunçdoğan İstanbul: Kitap Yayınevi, 2006, s. 226. Tavernier ayrıca en iyi şaraplık üzümlerin Olimpos Dağının güneyine bakan eteklerde yetiştiğini ve bu şarapların içiminin ise nefis olduğunun altını çizer bkz. a.g.e., s.226.

${ }^{23}$ Osmanlı idaresinde Kıbrıs, (yay. haz.), Hacı Osman Yıldırım, Ankara: Devlet Arşivleri Genel Müdürlüğü, 2000, s.43.

${ }^{24}$ Kinneir, a.g.e., s. 182.

${ }^{25}$ Ali Efdal Özkul, “Osmanlı Kıbrıs'ında İpek Üretimi ve Ticareti”, Tarih ve Medeniyetler Tarihi, C.V, Ankara: Atatürk Kültür Dil ve Tarih Yüksek Kurumu, 2012, s.2397; Ayrıca ipek çeşitleri ile ipek üretimi ve ticareti için daha detaylı bilgi için bkz. Zahide İmer "Miladi Dönem Öncesi Orta Asya'da İpek”, Bilig, S. 32, 2005, s.6-11.

${ }^{26}$ Özkul, "İpek Üretimi ve Ticareti”, s.2396-2397.

27 Özkul,“İpek Üretimi ve Ticareti”, s.2397; C. D. Cobham, Excerpta Cypria: Materials for a History of Cyprus, Nicosia.1969, s.372, 373 ve 425. Ayrıca Özkul'un İngilizce olarak kaleme aldığ çalışma için bkz Özkul, "Silk Production and Trade in Ottoman Cyprus", Studies on Ottoman Cyprus, Festschrift in Honor of Ioannis P. Theocharides, (ed. by) E. Balta, G. Salakidis, T. Stavrides, İstanbul 2014, ss.171-210.
} 
bulunmaktaydı. Renkli ipeklerin de eşit miktarda gönderildiği Venedik ve Livorno'da beyaz ipek tercih edilmesine rağmen, bu tercih Kuzey ülkelerindeki kadar öncelikli olmamıştır. Portakal rengi ipek ise, Türkler tarafından Kahire' de pazarlanmıştır. ${ }^{28}$ Bunun yanı sıra, adada üretilen ipek, dış piyasada değerli ve aranan bir ihraç malıdır. Kıbrıs ipeği genellikle Kahire'ye ihraç edilmekteydi. Ayrıca Kıbrıs ipeği zamanla imparatorluk içerisinde ve batıda ünlenecek ve aranır hâle gelecektir. Kıbrıs'ta ipeği ile ünlenen şehirlerarasında Değirmenlik, Baf, Evdim, Gilan ve Mağusa yer almaktadır. ${ }^{29}$ Tavernier de benzer şekilde Kıbrıs'ta ipek üretilen en önemli yerin Kythrea (Değirmenlik) olduğunu vurgular. Ayrıca seyyah Limasol ve Baf arasında bulunan bazı köylerde de ipek üretildiği bilgisini verir. ${ }^{30}$ Fakat Kinneir, tuz gibi adanın diğer önemli ihraç malları hakkında herhangi bir bilgi vermez. ${ }^{31}$ Bunun muhtemel nedeni, ilgisini çeken ürünlerle ilgili bilgi vermesi olabilir. 18. yüzyıl ortalarında Kıbrıs'tan batı ülkelerine yılda 1.115 .750 kuruş tutarında ipekli ve pamuklu kumaş, yün, tütün, şarap, içki ilaç ve boya yapımında kullanılan değerli bitkilerle, 601.500 kuruş değerinde çeşitli kumaş ve dokuma ihraç edildiği görülmektedir. ${ }^{32}$ Seyyah ayrıca adada yüksek kalitede buğday üretildiğini de söylemektedir. Buna ek olarak, Kinneir, adadaki köylülerin toprağ1 pirinç ekimi için hazırlayabilecek kadar parasal güce sahip oldukları takdirde adanın çeşitli yerlerinde pirinç yetiştirmenin de mümkün olabileceğini vurgular. ${ }^{33}$ Seyyahın verdiği bilgilere bakılırsa, adada tarımla uğraşan köylülerin yeterli kapitale sahip olmadıkları, yani fakir oldukları anlaşılmaktadır.

Kinneir, İngiltere'nin adada nüfuz sahibi olmasının ekonomik bakımdan nasıl birtakım avantajlar sağlayacağı konusunda da bilgiler aktarır. Örneğin, Anadolu'nun afyon, pamuk ve tütününü, Mısır'ın pirinç ve şekerini ve Kıbrıs'ın ünlü şarap ve ipeği ile diğer ürünlerini dünyaya pazarlayarak, İngiltere'nin ticaret hacmini arttırabileceğinin altını çizer. ${ }^{34}$ Gerçekten de Ortadoğu ve Akdeniz'in kontrolünü ele geçirmek isteyen bütün devletler için Kıbrıs adası, her daim önemli bir üs olarak görülmüştür. Dolayısıyla adayı elinde tutan devletlere Kıbrıs, aynı zamanda Anadolu, Misır, Lübnan ve İran'a kadar uzanan bölgeyi de kontrol edebilme firsatı sunmaktayd. ${ }^{35}$ 19. yüzyılın başlarında Osmanlı Devleti açısından bazı dengeler değişmişti. Çünkü Osmanlı Devleti sürekli savaş ve iç savaşlar ile uğraşmış ve bu nedenle önemli ölçüde yıpranmıştı. Ancak bu defa karşısına Akdeniz'de kendi menfaatlerine yönelik nüfuz elde etmeye çalışan İngiltere ve Fransa çıkmıştı. Osmanlı Devleti değişen dengeler nedeniyle ayakta kalabilmek için bazen ayrı ayrı bazen de bu iki devletle beraber ittifak arayışı içine girmiştir. İngiltere için Osmanlı Devletinin toprak bütünlüguü Hindistan yolunun emniyeti açısından önem taşımaktaydı. Seyyahın da belirttiği gibi, Osmanlı Devleti İngiliz politikalarına tehdit oluşturan Rusya'yı durdurabilecek önemli bir devlet olarak görülmekteydi. Bununla birlikte, Fransa'nın Mısır'a ilgisi de göz önüne alındığında, Kıbrıs'ın İngiltere için taşıdığı jeo-stratejik, jeo-politik ve ekonomik önem daha açık hale gelmektedir. ${ }^{36}$

\footnotetext{
${ }^{28}$ G. Mariti, Travels in the Island of Cyprus, First published in Lucca in 1769 as "Viaggiper L'IsoladiCipro", (trans. from Italian by) Claude Deleval Cobham, Unchanged Reprint of the Edition London 1909, London: Zeno 1971, s.113.

${ }^{29}$ Cobham, a.g.e., s. $372,373,425$.

${ }^{30}$ Tavernier Seyahatnamesi, s.227.

${ }^{31}$ Cobham, a.g.e., 372,373, 425; Çiçek, "Kıbrıs", s.378.

${ }^{32}$ Çiçek, "Kıbrıs", s.378. Bununla birlikte, adada 18. yüzyılda ipekle ilgili ürün ve fiyatlara dair bkz. Özkul, "İpek üretimi ve Ticareti", s.2400-2401.

${ }^{33}$ Kinneir, a.g.e., s. 182 .

${ }^{34}$ Kinneir, a.g.e., s. 186 .

${ }^{35}$ Ahmet Atasoy, "Kuzey Kıbrıs Türk Cumhuriyetinin Nüfus Coğrafyası", Mustafa Kemal Üniversitesi Sosyal Bilimler Enstitüsü Dergisi, C.8, S.15, 2011, s. 31-32.

${ }^{36}$ Durmuş Akalın, Cemil Çelik, "XIX. Yüzyılda Doğu Akdeniz’de İngiliz-Fransız Rekabeti”, Turkish Studies, Vol.7/3 2012, s.23-24. I. Napolyon, Akdeniz’de kendisine en büyük rakip olarak İngiltere’yi görüyor ve İngilizleri Akdeniz'den çıkarmak ve Süveyş bölgesi ile Kızıldeniz'de bulunan önemli İngiliz ticaret üslerini ele geçirmek ve bu şekilde Uzakdoğu'daki İngiliz hâkimiyetine bir son vermek istiyordu. Bunu hayata geçirebilmek için Hindistan'a giden en kısa yol olan Mısır'ın ele geçirilmesi gerekiyordu. Bu nedenle 19. yüzyılın hemen öncesinde 1798 yılının Mart ayında Fransa Mısır'a asker çıkararak Akdeniz'de İngilizlerin aleyhine olacak çıkarlarını sağlamlaştırma yönünde adım attı. Mısır seferi Doğu Akdeniz'de ve Kıbrıs'ta Osmanlı Devletini birtakım tedbirler almaya itti. Ada, Fransa'nın işgali nedeniyle açılan savaşta Osmanlı ordusuna nakliye üssü işlevi görmesi, işgal merkezinde yaşanan gelişmelerin merkez e iletilmesi gibi konularda oldukça etkin bir rol üstlenmişti. Savaşsırasında İngiltere bölgedeki çıkarları nedeniyle Osmanlı Devleti ile
} 
Görüldüğü üzere, Kinneir, gezi notlarında adanın sahip olduğu jeo-stratejik ve jeo-politik önemin, İngiltere açısından sağlayacağı siyasi ve ekonomik avantajları üzerinde yoğunlaşarak bazı değerlendirme ve analizler yapmaktadır. Dolayısıyla gezi notlarında aktarılan bilgilerden hareketle, onun sıradan bir seyyah gibi hareket etmediğini ve başat amacının ülkesinin siyasi ve ekonomik çıkarlarını gözetmek ve bu doğrultuda bilgi toplamak olduğunu belirtmek gerekir. Seyyahın 19.yüzyıl başında adada bulunduğu göz önünde bulundurulursa, İngiltere'nin bölgedeki siyasi ve ekonomik menfaatlerini gözetmek adına, adaya neden özel bir ilgi gösterdiği ve adanın sosyal, siyasi, idari ve ekonomik yapısı hakkında neden bu kadar ayrıntılı bilgi toplamaya çalıştı̆̆ da daha açık hale gelir.

Seyyah, 19. yüzyıl başlarında adanın sahip olduğu nüfusa dair de bilgiler sunar. Ona göre, adanın nüfusu tahminen 70.000'in biraz üzerindedir. Ayrıca adada her geçen gün nüfus azalmaktadır. Bu nüfusun yarısı Rumlardan diğer yarısı ise Larnaka'da yaşayan Frenk nüfus hariç Müslümanlardan oluşmaktadır. ${ }^{37}$ Seyyahın verdiği bilgilerden adada Larnaka'da meskûn olan Frenkler hariç 35.000 kadar Hıristiyan ve 35.000 kadar Müslüman nüfus yaşadığı anlaşılmaktadır. Seyyahın da aktardığı gibi, adanın nüfusunda tarihsel süreçte belli oynamaların yaşandığı görülmektedir. Adanın önceki dönemlere ait nüfus verilerini tahrir defterlerinden takip etmek mümkündür. Kıbrıs'ın fethinden sonra yapılan 1572 tarihli tahrire göre adada bulunan şehirlerde toplam 1915 hâne, köy ve mezralarda ise 32.032 hâne bulunuyordu. Ayrica defterde 419 kişi "neferen", 207 kişi de "cemâat-i tâife-i Kıptiyân-1 perakende" olarak kaydedilmiştir. Buna göre bir hânede ortalama beş kişi olduğu var sayımından yola çıkılarak, adanın fetihten hemen sonrası nüfusunun 170.000-175.000 kişi olduğu tahmin edilebilir. Bu nüfusun büyük çoğunluğunu, Ortodoks Rumlar oluşturmaktaydı. Osmanlı Devleti izlediği iskân politikası gereği fetihten sonraki yıllarda da Kıbrıs'a, Anadolu'dan nüfus nakline devam etmiştir. ${ }^{38}$ Çiçek, 1581 tarihli bir belgeye göre, ilk on yılda adaya 12.000 hânenin nakledilmesinin planlandığını, ancak bunların üçte birinin adaya hiç gelmediği belirtir. Buna rağmen fetihten on yıl sonra sürgünlerle adada bulunan Türk varlığının önemli bir orana ulaştığı ve genel olarak adanın nüfusunun arttığ 1 anlaşılmaktadır. Ermeni, Mârûnî ve Yahudilerin nüfusu ise önemsenmeyecek kadar azd1. ${ }^{39}$ Adaya gelen bazı seyyahlar da 1590'larda Lefkoşa, Mağusa, Girne ve Baf gibi şehirlerin önemli ölçüde Türkleştiğinin altını çizerler. Kıbrıs Eyaletinin, 1750-1800 yıları arasında sahip olduğu toplam nüfusa dair dönemin arşiv kayıtlarından bazı bilgilere ulaşmak mümkündür. Sözgelimi, 1777 yılı için en önemli kaynaklardan birisi Kıbrıslı Hıristiyan din adamlarından ve aynı zamanda tarihçi olan Cyprianos'tur. Onun aktardığına göre, adanın 37.000'i Hıristiyan ve 47.000'i Müslüman olmak üzere toplam nüfusu 84.000 idi. ${ }^{40}$ Bununla birlikte, Çevikel ada nüfusu hakkında belgelere dayalı olarak yaptığı bir çalışmada, 1790 yılında adanın toplam nüfusunun 115.724 (Müslümanlar 67.000, Zimmiler 48.724) ;1793 yılı için 114.616 (Müslümanlar 67.000, Zimmiler 47.616) olduğunu belirtir. 19. yüzyılın başında, Müslümanlar 67.000, Zimmiler 30.524 olmak üzere toplam nüfus 97.524 olarak verilir. ${ }^{41} 19$. yüzyılın hemen başında verilen nüfus verileriyle seyyahın tahminen verdiği nüfus verisi mukayese edildiğinde ada nüfusunda önemli bir azalma olduğu dikkat çekmektedir. Yine rakamlar iyice incelenirse, Türk nüfusundan ziyade gayrimüslim nüfusta azalmaların yaşandığını kaydetmek gerekir. Ada nüfusunun zaman zaman azalma göstermesinin doğal ve beşerî olmak üzere iki nedeni olduğu söylenebilir. Doğal sebepler arasında istilalar, kuraklık, kıtlıklar, veba hastalığı, çekirge sürüleri vb. gibi faktörler yer

ittifak yapmış ve I. Napeleon herhangi bir başarı elde edemeden Mısır'ı terk etmek zorunda kalmıştır. Ancak İngiltere Fransa'nın Mısır'ı terk etmesinden sonra bölgede doğrudan kendisi hâkimiyet kurmak istemiştir. Fakat zor da olsa Osmanlı Devleti İngiltere'yi bu isteğinden vazgeçirebilmiş̧ir bkz. a.g.m., s.25-26.

${ }^{37}$ Kinneir, a.g.e., s. 181.

${ }^{38}$ Çiçek, "Kıbrıs", s.376.

39 Çiçek'in aktardığına göre, 1596'da adayı ziyaret eden Dandini, Müslüman nüfusunu 12-13.000 kişi olarak bildirirken, Cotovicus1599'da bu sayı1 6000 erkek nüfus olarak vermektedir bkz. Çiçek, "Kıbrıs", s.376.

${ }^{40}$ Çiçek, "Kıbrıs", s.377.

${ }^{41}$ Nuri Çevikel, "Osmanlı Kıbrıs'ında Müslim-Gayrimüslim İlişkileri ve ihtida Meselesi (1746-1801)”, Tarih ve Medeniyetler Tarihi, C.II, Ankara: Atatürk Kültür Dil ve Tarih Yüksek Kurumu, 2012, s.942. Yine 1729-1750 yılları arasında adanın sahip olduğu nüfusa dair değerlendirmeler için bkz. Özkul, Kıbrıs'ın Sosyo- Ekonomik Tarihi (1726-1750), s.199-211. 


\section{F.Ü. Sosyal Bilimler Dergisi 2019-29/1}

almaktadır. ${ }^{42}$ Örneğin, nüfustaki azalmada önemli bir etkisi olan bu doğal faktörlerin başında veba hastalığı gelmektedir. Panzac'a göre, 18. yüzyılda daha yoğun olmak üzere, 19. yüzyılda Tanzimat öncesi dönemde de Osmanlı topraklarında veba görülmeye devam etmiştir. Hatta bu hastalık ada nüfusunun sekizde birini yok etmiştir. ${ }^{43}$ Doğal faktörlerin yanı sıra adadaki nüfusun azalmasında kimi beşeri faktörlerin de etkisi olmuştur. Zaman zaman Osmanlı yönetiminin sert emirlerini içeren fermanlarla uyarılan yöneticilerin birtakım tutum ve davranışları buna örnek gösterilebilir. Ayrıca kilise yöneticileri ve yönetici konumundaki kişilerin halktan usulsüz vergi almaları nüfusun azalmasına yol açmıştır. Özellikle ada nüfusunun ilgili dönemlerde azalmasında en önemli olan beşerî faktörlerden biri de savaşlar olmuştur. ${ }^{44}$

Adada nüfusun azalmaya başlaması aslında 17-18. yüzyıllara değin geriye gider. Nitekim Kıbrıs'ın merkezden uzaklaşmaya, isyanlar ve sosyal çalkantılarla birlikte yavaş yavaş ayanların kontrolüne girmeye başladığı 18.yüzyılda, nüfusunda önemli bir azalma görülür. Bu azalma gayrimüslimler bakımındandır. Şer'iyye sicilleri ve seyyahların gezi notlarında aktarılan kimi bilgilere bakılırsa, adada yaşayan Müslümanların oranı gittikçe artmıştır. Ancak Lefkoşa sicillerinde cizye ve nüzul vergisiyle ilgili kayıtlarda, 1699-1726 yılları arasında "8.000 zinde ve mevcut" Hıristiyana karş1lık "4.500 dirlikli ve dirliksiz Müslüman" olduğu belirtilmektedir. Çiçek, vergi muafları da dâhil edildiğinde 18. yüzyılın ilk yarısında ada nüfusunun yarısına yakının Müslüman olduğunu söyler. ${ }^{45}$ Özkul 1726-1750 y1lları arasında Kıbrıs adasında 41.000 ila 44.000 arasında değişen bir gayrimüslim nüfus yaşadığını ve araştırılan yıllara ait olan kaynaklarda yalnızca üç yıla ait dirliksiz Müslümanların sayısına ilişkin bilgi bulunduğunu söyler. Elde edilen bu kayıtlara göre ise, adada yaşayan dirliksiz Müslümanların sayısının 9.022 ila 4.188 arasında değişiklik arz ettiğini belirtir. ${ }^{46}$ İlk Osmanlı genel nüfus sayımında ise, 14.983'ü Müslüman olmak üzere toplam 44.206 erkek nüfus olduğu görülmektedir. Buna kadınlar da eklendiğinde nüfusun 90.000 civarında olduğu anlaşılmaktadır. 1841 'de yapılan nüfus sayımı ile elde edilen bilgilere göre ise, adada yaklaşık olarak 30.000 Türk, 70.000 Rum ve kalanı da Ermeni, Marunî ve Katolik olmak üzere toplam 110.000 kişi yaşamaktaydı. Takip eden yıllarda da adadaki nüfus artışı devam etti. Örneğin, 1858 tarihli bir İngiliz konsolosluk raporunda adadaki toplam nüfus 180.000 'dir. Bu rapora göre, adadaki meskûn köy sayıs1 605 olup, bunların 118'i Türk, 248'i Rum ve geri kalanı karma idi. Adanın İngilizlere devrinden sonra yapılan ilk nüfus sayımı sonucuna göre ise adada 185.630 kişi yaşıyordu. ${ }^{47}$

Kinneir'in Kıbrıs adasında ilk ziyaret ettiği yerin Mağusa olduğu anlaşılmaktadır. O, ilk olarak beraberindeki bir mihmandar ve hizmetçi ile birlikte 16 saatlik bir deniz yolculuğundan sonra Mağusa'ya ulaştıklarını söyler. Akabinde kentin limanı hakkında okuyucuya bazı bilgiler verir. Ona göre, liman 80 ila 100 yard $^{48}$ geniş likte olup, bir taraftan bir kale diğer taraftan ise, harabe durumunda olan kule tarafından savunulmaktadır. Ayrıca bir zamanlar liman çok sayıda geminin demir attı̆ğ bir yerken, Türklerin adayı ele geçirmesinden sonra kum ve birtakım atıkların birikmesi neticesinde artık küçük gemiler haricinde hiçbir gemi limana güvenli bir şekilde girememektedir. ${ }^{49}$ Seyyahın da belirttiği gibi, Osmanlı döneminde Mağusa'daki liman faaliyetleri çeşitli nedenlerle azalmış, aynı zamanda limanın fiziksel koşulları da zaman içerisinde değişime uğramıştır. Bu değişimlerden birisi, Pedios (Kanlıdere) nehrinin taşıdığı toprakların limanda birikmesi sonucu limanın gemiler tarafından

\footnotetext{
${ }^{42}$ Ahmet Atasoy, "Kuzey Kıbrıs Türk Cumhuriyetinin Nüfus Coğrafyası", Mustafa Kemal Üniversitesi Sosyal Bilimler Enstitüsü Dergisi, C.8, S.15, 2011, s.33.

${ }^{43}$ Daniel Panzac, Osmanlı İmparatorluğu'nda Veba (1700-1850),(çev. ) Serap Yılmaz, İstanbul: Tarih Vakfi Yurt Yayınları, 1997, s.34, 73, 169.

170.

${ }^{44}$ Nuri Çevikel, Kıbrıs Akdeniz'de Bir Osmanlı Adası (1570 -1878), İstanbul: Tarih İnceleme Dizisi, 2001, s.214-215.

${ }^{45}$ Çiçek, "Kıbrıs", s.377.

46 Özkul, a.g.e., s.207.

${ }^{47}$ Çiçek, "Kıbrıs", s.376-377.

${ }^{48}$ Bir Yard 0,9144 metreye (1 metre yaklaşık 1,0936 uluslararası yardadır) eşittir.

${ }^{49}$ John McDonald Kinneir, Journey Through Asia Minor, Armenia and Koordistan in the years 1813 and 1814, London 1818, s.176-177.
} 
kullanımını güçleştirmesi oluşturmaktadır. ${ }^{50}$ Tavernier de kentin küçük limanının büyük gemilere hizmet veremediğini belirtir. ${ }^{51}$ Gerek Tavernier'in gerekse Kinneir'in verdiği bilgilerden kentin limanının sahip olduğu fiziki koşulların yetersiz olduğu anlaşılmaktadır. Ancak Kinneir'in limanda coğrafi bir gelişme sonucu ortaya çıkan bu durumu göz ardı ederek, limanın kullanım güçlüğü ve işlevsizliğinin Türklerden kaynaklandığına vurgu yaptığı dikkat çekmektedir. Seyyah, devam eden satırlarda limandaki gümrük görevlilerin kendisinden bahşiş istediklerini, ancak onların bu isteklerine aldırış etmeden şehrin merkezinde bulunan kahvehaneye doğru 1ssız ve harap halde bulunan kiliselerin bulunduğu cadde boyunca yürüyerek gittiğini belirtir. ${ }^{52}$ Görüldüğü üzere, Kinneir'in gerek kentin limanının sahip olduğu fiziki koşullarını gerekse kentin merkezine doğru giden yol güzergâhını olumsuz bir şekilde betimlediği görülmektedir.

Kinneir, kentin adının menşei ve konumu hakkında da kimi bilgiler aktarır. O, Mağusa'nın (Famagusta) adını Amachostos burnundan aldığını ve şimdi Eski Mağusa olarak bilinen antik Salamis'in 5 mil $^{53}$ kadar yukarısında kurulu olduğunu söyler. Ardından 19. yüzyılda Osmanlı topraklarına gelen seyyahların eserlerinde öncelikli olarak değindikleri kentin tarihi geçmişine değinir. Kentin ilk olarak bir Bizans kolonisi tarafından kurulduğunu, Luzinyanlar ${ }^{54}$ devrinde daha da güçlendiğini ve sonrasında Venedikliler tarafından bayındır hale getirildiği bilgisini verir. Böylece kentin kısa bir tarihi geçmişini aktarır. ${ }^{55}$ Buna ek olarak, kentin Sultan Selim'in uzun ve zorlu kuşatmasına karşı koyduğunu, bunun kanıtının ise, kentin kalesi olduğunu söyler. Ancak geçmişte oldukça sağlam olan kaleden geriye yaklaşık olarak 2 mil boyunca kenti çevreleyen duvarlar ve sert kayanın oyulması ile yapılmış ve geniş bir hendekle kara tarafında savunulan kale burçları ve bir surun dışında fazla bir hatıra kalmamıştır. Ona göre, Osmanlılara karşı kenti savunan soylu kişi Brigardine adında biridir. $\mathrm{O}$, bu kahramanın derisinin, vahşi düşman tarafından yüzüldüğünü ve vücudunun samanla doldurularak bir direğe ibretlik olarak asıldığını vurgular. ${ }^{56}$ Fakat Kinneir'in kentin antik geçmişi hakkında bilgi aktarırken gelmiş olduğu ülkenin kültürünün etkisi altında kalarak kimi bilgiler verdiği ve okuyucu üzerinde adanın sanki Osmanlı hâkimiyeti altına girmesi ile eski canlılığını ve bayındır halini kaybettiği gibi bir izlenim uyandırmaya çalıştı̆̆ anlaşılmaktadır. Aslında nesnel olmayan bu bakış açısının, özellikle 19. yüzyılda Osmanlı coğrafyasına gelen pek çok seyyahın eserinde bazen örtük bazen de açık bir şekilde yer aldığı söylenebilir. Şöyle ki; seyyahların ekseriyetinin uzun zamandır Türklerin elinde olan bir Osmanlı yerleşim biriminin antik geçmişi hakkında bilgi verirken sıkça Osmanlı öncesi dönemine atıfta bulunmaları ve bölgenin geçmişini Hellen kültürü ile başlatma gibi bir eğilim içinde hareket etmeleri söz konusudur. Aslında bu durum onların Hellen kültürüne olan ilgilerinin bir yansıması olarak da değerlendirilebilir. ${ }^{57}$ Bununla birlikte, Kinneir, Mağusa'nın merkezinde birkaç Türk ailenin ikamet ettiğini ve kent merkezinde harap durumda olan ve adını vermediği bazı kilise yapılarının yer aldığını söyler. Ayrıca Venedikliler

\footnotetext{
${ }^{50}$ Ege Uluca, Gazimağusa Kaleiçi'nin Tarihsel Süreç Iç̧indeki Kentsel Gelişimi ve Değişimi, İstanbul Teknik Üniversitesi Fen Bilimleri Enstitüsü, Yayınlanmamış Doktora Tezi, İstanbul 2006, s.99.

${ }^{51}$ Tavernier Seyahatnamesi, (çev.)Teoman Tunçdoğan, İstanbul: Kitap Yayınevi 2006, s.225. Ancak 19. yüzyıldan sonra Mağusa limanı Larnaka ve Limasol limanlarından sonra en işlek üçüncü liman olma özelliğine sahip olmuştur. Örneğin adaya gelen seyyahlar Kıbrıs'ın birkaç tane limanı olmasına rağmen, bu limanların Levant kıyılarına nazaran daha korunaklı ve emniyetli olduğunu dikkat çekerler. Bununla birlikte, Larnaka, Limasol ve Mağusa limanlarının yanı sıra Baf (Paphostan) da söz edilmektedir bkz. Ali Efdal Özkul, "The Consuls and their Activities in Cyprus Under the Ottoman Administration (1571-1878)", Turkish Studies, Vol. 8/2, 2013, s.244.

${ }^{52}$ Kinneir, a.g.e., s. 177.

${ }^{53}$ Bir kara milinin uzunluğu metrik hesaba göre 1.609,344 metredir.

${ }^{54} 15$.yüzyılın ünlü Kıbrıslı vakanüvisti, Kral Richard'ın Templar Şövalyelerinin iadesinin ardından, yeni bir anlaşmayla adayı 100,000 altın dukaya o sırada Kudüs Kralı olan Guy de Lüzinyan'a sattığını belirtmektedir. Kıbrıs'ın yeni sahibi Guy de Lüzinyan, evlilik yoluyla 1186 yılında Kudüs Kralı unvanını almış olan Frenk kökenli Lüzinyan ailesine mensup olan bir soyludur. Bu aile 1192-1489 yılları arasında adada söz sahibi olmuştur bkz. Uluca, a.g.t., s.53. Bu konuda daha detaylı bilgi için bkz. L. Makhairas, Recital concerning the Sweet Land of Cyprus (1458),(ed. and trans. by) R.M. Dawkins, Vol.I, Oxford: Clarendon Press 1932,s. 20 vd.

${ }^{55}$ Kinneir, a.g.e., s.177.

${ }^{56}$ Kinneir, a.g.e., s. 177

${ }^{57}$ Y1lmaz, a.g.t., s. 20.
} 
dönemine ait olan sarayın ${ }^{58}$ bazı kalıntılarının da Gotik mimari sanatının saygın simgelerinden olan St. Sophia katedralinin hemen yanında yer aldığını belirtir. Bu katedralin bir kısmının camiye çevrildiğini sözlerine ekler. ${ }^{59}$ Seyyahın verdiği bilgilere bakılırsa, kentin en önemli simgelerinden biri St. Sophia katedralidir. ${ }^{60}$ Seyyah, kentte Osmanlı dönemine ait olan, Akkule mescidi, Gazimağusa medresesi, Cafer Paşa çeşmesi ve hamamı gibi yapılar hakkında okuyucuya hiçbir bilgi aktarmaz. ${ }^{61} \mathrm{Bu}$ onun Mağusa' da dikkatini çeken şeylerin, kendi kültür geçmişine ait yapılar olduğu biçiminde yorumlanabilir. Devam eden satırlarda, seyyah, kalenin içinde kalacak bir yer bulamadığı için civardaki bir Rum köyünde bir oda kiraladığını ve ertesi gün antik kent Salamis'in ${ }^{62}$ kalıntılarını görmeye gittiğini belirtir. ${ }^{63}$

\section{O, Eski Mağusa'ya dair şöyle der:}

"Salamis tamamen sular altında kalmıştır. Bu kalıntılar bir daire biçiminde olan 3 yahut 4 mil olan eski kale duvarlarından, yağmur sularını biriktiren eski sarnıçları, kırık sütunlar sahil boyunca dağınık bir şekilde uzanan bazı yapıların temellerinden oluşmaktadır. Mă̆usa ve Salamis kalıntılarının bulunduğu coğrafya ise kumlu, rüzgârlara açık ve kayalıktır. Bu nedenle, topră̆ın büyük bir kısmı tarıma müsait değildir. Her yerde Arabistan çöllerindeki deve dikenine benzeyen zararlı otlar dışında hiçbir şey yoktur." ${ }^{64}$

Görüldüğü üzere, seyyahın Mağusa'da kaldığı kısa zaman dilimi içinde pek çok batılı seyyahın yaptığı gibi ilk olarak kentin fiziki yapısı hakkında bazı bilgiler verdiği ve bu bilgileri verirken özellikle kentin Helenik ve Hıristiyan dönemine kimi atıflar yaptı̆̆ 1 dikkat çekmektedir. Ayrıca seyyah özellikle antik kent Salamis'in olduğu yerin ikilim ve bitki örtüsü bakımından tarım yapmaya müsait olmadığını da sözlerine ekler.

\section{Larnaka}

Seyyahın bir sonraki durağı, 9 gün kaldığı Larnaka'dır. Verdiği bilgilerden Larnaka'da İngiliz Konsolosunun evinde konakladığı ve kaldığı süre zarfında Larnaka ve civarında çeşitli gezintiler yaptığı anlaşılmaktadır. Seyyah ilk olarak okuyucuya Larnaka'nın coğrafi konumunu tanıtır. O, Larnaka'nın antik Citium (Kition) kenti üzerine kurulu olduğunu belirtir. Ona göre, ticari önem bakımından burası Kıbrıs'taki ikinci önemli kenttir ve şehirde çeşitli batılı devletlerin konsoloslukları bulunmaktadır. ${ }^{65}$ Devam eden satıllarda seyyah, kentin fiziki yapısını betimlemeye yönelir. Kinneir, kentin Aşağı ve Yukarı Larnaka olmak üzere iki kısımdan oluştuğunu söyler. O, kentte bulunan evlerin topraktan yapılmış ve oldukça konforsuz olduğunu aktarır. Fakat ona göre, Frenklerin yaşadıkları evler her bakımdan daha konforludur. Yukarı Larnaka'da bir manastır ve piskoposun ikamet ettiği St. Saviour katedrali yer almaktadır. Aynı zamanda ihtişamdan uzak ve oldukça eski olan St. Lazarus şapeli de buradadır. Ayrıca St. Lazarus şapeline oldukça yakın bir

\footnotetext{
${ }^{58}$ Gazimağusa Kaleiçi’nde, Namık Kemal meydanının güney-batısında yer alan saray yapısı, ya da yaygın olarak bilinen adıyla Venedik Sarayı, meydanın ve kentin en önemli öğelerinden biridir. Yapım yılı, Lüzinyan Krallı̆̆g'nın erken dönemlerine kadar uzanan saraydan, 'dominiregis' veya 'dominiregis Cipri' tanımlarıyla Cenevizli noter Lambertodi Sambuceto'nun 1300-1302 tarihli kayıtlarında birçok kez söz edilmiştir. Ancak, Gazimağusa’yı Lefkoşa’dan sonraki ikinci ikametgâhları haline getiren Lüzinyan krallarından hangisinin sarayın yapımından sorumlu olduğu kesin olarak bilinmemektedir bkz. Uluca, ag.t., s.111-112.

${ }^{59}$ Kinneir, a.g.e., s.177-178.

${ }^{60}$ Seyyahın Mağusa kent merkezinde kentte bulunan tarihi yapılara dair çok detaylı gözlem ve incelemeler yapmadığı anlaşılmaktadır. Çünkü Mağusa'da çok sayıda kilise bulunmaktadır. Bunlar arasında St. Nicholas katedrali (Lala Mustafa Paşa cami), St. Peter ve Paul kilisesi (Sinan Paşa cami), St. George Latin kilisesi, St. George Yunan kilisesi ve St. Symeon şapeli, Fransiskan (St. Francis) kilisesi gibi yapılar yer almaktadır. Bu konuda daha detaylı bilgi için bkz. Uluca, a.g.t., s.114-139.

${ }^{61}$ Uluca, a.g.t., s.139.145.

${ }^{6}$ Salamis, antik Yunan dönemi boyunca, adadaki kent krallıklarının lideri olmuştur. Aristo gibi antik dönemde yaşamış ünlülerin de yetişmiş olduğu bu yerin, döneminin zengin ve parlak kentlerinden biri olduğu bilinmektedir bkz. F. G., Maier, Cyprus: From Earliest Time to the Present Day, (trans. from German by) Peter Gorge, London: Elek Books Ltd, 1968, s. 10 .

${ }^{63}$ Kinneir, a.g.e., s.177-178.

${ }^{64}$ Kinneir, a.g.e., s. 178 .

${ }^{65}$ Kinneir, a.g.e., s. 183.
} 
noktada, kentin kalesinin yer aldığını da sözlerine ekler. Ona göre, bu kale Luzinyanlar döneminde inşa edilmiştir ve oldukça harap bir durumdadır. ${ }^{66}$

Buna ek olarak, Kinneir, Larnaka'nın hemen yanındaki burnun hala Chitti olarak adlandırıldığını ve antik şehrin kalıntılarının, bir tümülüsü ya da bir tepeyi andıran toprak ve çöplerin oluşturduğu yığınlar arasından görüldüğünü söyler. $\mathrm{O}$, ayrıca yerli halk tarafından antik kalıntıların arasından yüksek kaliteli taşların ve değerli olabilecek birtakım eşyaların kazılarak çıkarıldığının altını çizer. ${ }^{67}$ Tavernier de benzer şekilde Lefkoşa'da bulunduğu esnada, Türklerin gizli kalmış kimi hazineleri aramak için Venedikliler döneminden kalma güzel sarayları yıktıklarını ve taşlarını ise yeni evlerin yapımı için sattıklarını belirtir. ${ }^{68}$ Seyyahın verdiği bilgilerden antik kent kalıntılarının gösterilen özensizlik neticesinde yeterince koruma altına alınmadığı ve yerli halk tarafindan yapılan kazılarla bu değerli hazineye zarar verildiği anlaşılmaktadır.

Seyyah Eski ve Yeni Larnaka'nın fiziki yapısı hakkında şöyle der:

"Eski ve Yeni Larnaka arasında, üzerinde bir binanın inşa edilmiş olduğu yüksek bir nokta bulunmaktadır ve bu yükseltinin hemen ağzında eski dönemlerde gemilerin demir attığı geniş̧̧e bir kısım bulunmaktadır. Ancak burası kum ve taşlarla dolduğu için, özellikle yaz aylarında su (azaldığ için) durgunlaşmakta ve etrafa kötü kokular yaymaktadır. Larnaka'nın suyu çok kaliteli olmadığı için eski dönemlerden kalma su sarnıcının ve uzun çukurların izleri görülebilmektedir. Ayrıca kentin su ihtiyacı, yaklaşık olarak 50 yll önce bir Türk emiri tarafindan inşa ettirilen su kemerleri ile sağlanmaktadır." 69

Kinneir'in Larnaka'da kaldığı zaman zarfında hem kent içinde hem de kentin yakın çevresine birtakım gezintiler yaptığı ve gördüklerini dikkatli bir şekilde kayıt altına aldığı anlaşılmaktadır. Ancak Mağusa örneğinde olduğu gibi, kendisinin genellikle kentin Osmanlı öncesi dönemde sahip olduğu bazı Hıristiyan yapılar hakkında bilgi verdiği ve bu yapıları ön plana çıkartmaya çalıştı̆̆ dikkat çekmektedir. Seyyahın, Osmanlı dönemine ait olan yapılara dair hiçbir bilgi vermediği göze çarpmaktadır. Örneğin, Larnaka'da Osmanlı dönemine ait yapılar arasında Ulucami, Seyyid Ahmed cami ve bazı çeşmelerle Ebûbekir Paşa tarafindan yaptırılan su kemerleri ile kalenin yer aldığ 1 söylenebilir. Ayrıca Muaviye'nin Kıbrıs seferine katılan Ümmü Haram'ın defnedildiği yerde prehistorik üç büyük taşla yapılan türbe ve yanında 1760 yılında kurulan Türabi tekkesi ve 1816 yilında Kıbrıs Muhassilı Seydi Mehmed Emin tarafindan yaptırılan cami de yine kentte bulunan önemli yapılar arasında yer almaktadır. ${ }^{70}$

Seyyah okuyucuya Larnaka'nın sosyo-ekonomik yaşamına dair de bazı bilgiler aktarır. O, Aşağı ve Yukarı Larnaka'nın toplam nüfusunu 5.000 kişi olarak verir. Bu nüfusun içinde 40 kadar Frenk aile olduğunu geri kalan nüfusu ise, Rumlarla Müslümanların oluşturduğunu söyler. ${ }^{71}$ Ancak Rumların ve Müslümanların nüfusuna ilişkin herhangi bir sayısal veri sunmaz. Fetihten sonra kentin önem kazanmasında ve nüfusunun gerek etnik gerekse dini bakımdan çeşitlilik arz etmesinde hiç şüphesiz Osmanlıların Larnaka'ya yönelik olan izledikleri iskân siyasetinin etkisi olmuştur. Mağusa'nın alınmasından sonra, buradan çıkarılan Katolikler ile Anadolu'dan getirilen Türk nüfusun bir kısmı Larnaka'ya yerleştirilmiştir. Ancak kentin etnik ve dini bakımdan sahip olduğu nüfusa dair 19. yüzyılın ortalarına kadar sağlıklı veriler bulunmamaktadır. Fakat bölgeye gelen seyyahların gezi notlarında ve Şer'iyye sicillerinde bulunan kayıtlarda, kentin nüfus bakımından oldukça kozmopolit bir yapıya sahip olduğu anlaşılmaktadır. ${ }^{72}$ Sözgelimi, Balta 1831 nüfus sayımı verilerine dayanarak kaleme aldığı çalışmasında, Larnaka kazasının toplam nüfusunun 5.280 olduğunu ve bu nüfusun

\footnotetext{
${ }^{66}$ Kinneir, a.g.e., s. 184.

${ }^{67}$ Kinneir, a.g.e., s. 185.

${ }^{68}$ Tavernier Seyahatnamesi, s.225.

${ }^{69}$ Kinneir, a.g.e., s. 185.

${ }^{70}$ Kemal Çiçek, "Larnaka”, D.I.A, C.27, 2003, s.106.

${ }^{71}$ Kinneir, a.g.e., s.184.

72 Çiçek, "Larnaka", s.106.
} 
3.805'ni gayrimüslimlerin ve 1.475 'ni Müslümanların oluşturduğunu belirtir. ${ }^{73}$ Yine Osmanlı nüfus defterlerine dayalı olarak yapılan başka bir çalışmada, 1833 yılında Larnaka'nın toplam Müslüman nüfusu 3.516 kişi ve toplam gayrimüslim nüfus ise 7.532 kişi olarak verilmektedir. 1848 yılı için, Müslümanların toplam nüfusunun 1.824 kişi, gayrimüslimlerin toplam nüfusunun 9.022 kişi olduğu belirtilmektedir. ${ }^{74} 1850$ y1lında yapılan bir sayıma göre ise, kentte 849 Müslüman ve 2.426 gayrimüslim hane olduğu bilgisi verilmektedir. ${ }^{75} 1858$ y1lı için Larnaka'da yaşayan Müslümanların toplam nüfusunun 4.050 kişi, gayrimüslimlerin toplam nüfusunun ise, 7.972 kişi olduğu belirtilmektedir. ${ }^{76}$

Kinneir, Larnaka'nın ekonomik yaşamına da değinir. $\mathrm{O}$, ilk olarak kentin ihraç maddelerinin buğday, arpa, pamuk, ipek ve şarap olduğunu, ithal ettiği malların ise Mısır'dan pirinç ve şeker, Malta ve İzmir'den kumaş, madeni eşyalar ve kolonyal ürünler olduğunu söyler. Aslında 17. yüzyılın başlarında kentte bulunan bazı seyyahlar da kentin ticari önemine vurgu yaparlar. Örneğin, Beavau Larnaka'nın önemli bir ihracat limanı haline geldiğini söyler. Pietrodella Valle ise, kentin Levant'ta ${ }^{77}$ en sık uğranılan yerlerin arasında bulunduğunu ve burada çok sayıda yabancı tüccarın ve konsolosun ikamet ettiği bilgisini verir. ${ }^{78}$ Buna paralel olarak, Kinneir de kentteki ticaret trafiğinin İngiliz bayrağı taşıyan Levantenlere ait gemilerle yapıldığının altını çizer. Fakat kent ticaret faaliyetlerinin sağlıklı olarak yürütülmesini sağlayacak olan bir limana sahip olmadığından ötürü, gemiler kıyıdan belli bir mesafe uzaklıkta demir atmak zorunda kalırlar. Buna rağmen çok az sayıda kaza meydana gelir. ${ }^{79}$ Görüldüğü üzere Kinneir'in, Mağusa örneğinde olduğu gibi Larnaka'da da düzgün bir liman olmayışı üzerinde durduğu dikkat çekmektedir. Aslında kentin fethinden sonra emniyetli olmayan küçük liman, Osmanlılar tarafından buraya muhafızlar yerleştirilmek suretiyle güvence altına alınmıştır. ${ }^{80}$

\section{Lefkoşa}

Kinneir, Larnaka'dan ayrıldıktan sonra at sırtında adanın başkenti olarak söylediği Lefkoşa'ya doğru yola çıkar. Kent önlerinde gözükmeye başlayınca kente dair bilgi vermeye başlar. $O$, ilk olarak kentin eski adının Tamais olduğunu söyler. Akabinde kentin genel görünümünü tasvire koyulur. O, Lefkoşa'nın uzaktan genel hoş bir görüntü arz ettiğini ve hatta İran'daki Şiraz şehrine benzediğini vurgular. Ayrıca İran'ın başkenti gibi zirveleri karla kaplı ve yüksek dağlarla çevrili oldukça güzel bir vadide kurulu olduğunu ve ağaçların üstünden çok sayıda minarenin benzer şekilde yükseldiğini belirtir. Fakat dayanıklı kale duvarları ve burçların bir araya gelmesiyle oluşan ve kentte bulunan diğer binalar arasında belirgin bir şekilde fark edilen St. Sophia katedrali, Şiraz'ın bile boy ölçüşemeyeceği şekilde Lefkoşa'ya ayrı bir azamet katmaktadır. ${ }^{81}$ Seyyahın verdiği bilgilere bakılırsa, Lefkoşa'nın kendisini daha önce bulunduğu Mağusa ve Larnaka'ya nazaran daha fazla

\footnotetext{
${ }^{73}$ Evangalia Balta, Filiz Yaşar, Elif Bayraktar, "Gayr-i Muslims in Tuzla (Larnaca): The Census Register of 1831", Histrories of Otttoman Larnaca, (ed. by) Evangalia Balta-Theoharis Stavrides-Ioannis Theocharides, İstanbul: ISIS Press, 2012, s.143-144.

${ }^{74}$ Muhammed Köse, “Arşiv Belgelerine Göre XIX. Yüzyılda Kıbrıs Ceziresi Tuzla/Larnaka’nın Demografik Yapısı”, Osmanlı Döneminde Kıbrıs, İstanbul: Seçil ofset 2016, s.303

${ }^{75}$ Çiçek, "Larnaka", s.106.

${ }^{76}$ Köse, a.g.m., s.303. Köse, 1833 yılında 35 yerleşim birimindeki 3.516 kişiden oluşan Müslüman nüfusun, 1858 y1lında 32 olarak tespit edilen yerleşim biriminde toplam 4.050 Müslüman yaşadığını ve 25 yıllık süre içerisinde Larnaka'da yaşayan Müslümanların sayısında 534 kişilik bir artış olduğunu söyler. O, 1833-1858 yılları arasında Müslümanlara nazaran gayrimüslimlerin nüfuslarının daha fazla arttığını ve 25 yıllık süre zarfında gayrimüslimlerin nüfusunda 3.628 kişilik bir artış olduğunu ileri sürer bkz. Köse, a.g.m. s.302-303.

${ }^{77}$ Avrupa literatüründe10.yüzyıldan başlayarak Akdeniz'in doğu kıyılarındaki ülkelere verilen addır. Bkz. Şerafettin Turan, "Levant", D.I.A, C.27, 2003, s.145-147.

${ }^{78}$ Çiçek "Larnaka", s.106.

${ }^{79}$ Kinneir, a.g.e., s.184-185.

${ }^{80}$ Çiçek, "Larnaka", s.106. Bununla birlikte, Osmanlı idaresi Larnaka'yı her bakımdan geliştirme gayreti içinde olmuş ve bu doğrultuda kente 1625 yılında bir kale yaptırarak asker yerleştirmişti. Buna ek olarak, şehirde ikamet eden tüccar ve konsolosların can ve mal güvenliğini temin etmek için kendilerine korumalar verilmiştir bkz. Çiçek, "Larnaka", s.106.

${ }^{81}$ Kinneir, a.g.e., s.188.
} 
etkilediği anlaşılmaktadır. Çünkü Kinneir'in kentin genel görünümünü oldukça romantik bir üslupla betimlemesi oldukça dikkat çekicidir.

Seyyah, belli bir mesafeden gördüğü kentin genel görünümü hakkında bilgi verdikten sonra kentin iç fiziki yapısına yönelir. Kinneir, ilk olarak Lefkoşa'da her seyyahın dikkatini çektiğini düşündüğü yapıları görmeye gittiğini söyler. Ona göre, bu yapılar arasında St. Dominique, St. Catherine, St. Nicholas ve St. Sophia gibi katedraller yer almaktadır. Ancak bunların arasında St. Sophia katedralinin Gotik mimari üslubun en güzel örneklerinden birini temsil ettiğini, fakat diğerlerinin tasvir etmeye değecek özellikler taşımadığının altını çizer. Ardından bunlardan üçünün şimdi cami olarak hizmet verdiğini, St. Nicholas katedralinin bedestene çevrildiğini ve St. Dominique'te de Luzinyan dönemine ait bazı prenseslerin mezarlarının bulunduğu bilgisini verir. Devam eden satırlarda ise, şimdi bir mütesellimin ikamet ettiği, ancak bir zamanlar Kıbrıs krallarının sarayı olan bir yapıdan söz eder. Fakat yapı önemli ölçüde değişiklik geçirdiği için, orijinal hali hakkında bir fikir sahibi olmanın oldukça güç olduğuna değinir. Yapının oldukça büyük bir kapısı olduğunu, üstünde Luzinyan döneminden kaldığını düşündüğü bir hilalin yer aldığını söyler. ${ }^{82}$

Kinneir daha sonra kentin kalesini ziyaret eder. O, kalenin etrafını 1 saat 15 dakika gibi bir süre zarfinda yürüdügünü, surların kesilmiş taşlardan yapıldığını ve kale burçlarının ise, dikdörtgen şeklinde olduğunu söyler. Kale hendeğinin, kuru ve sığ olduğunu, ancak hendekler oldukça geniş olduğundan burada önemli miktarda mısırın yetiştirildiğini belirtir. Seyyah ayrıca kale duvarının olduğu yerin oldukça geniş ve bir bölümünün ekili olduğunu, ancak büyük miktarlarda çöp ve toprağın kaleyi güçlendirmek için kentin içinden buraya taşındığının altını çizer. Kalede bulunan bataryaların ise kullanılacak durumda olmadığını ve sadece dört küçük parçadan ibaret olduğunu ve bunların da oldukça kötü durumda bulunduğunun altını çizer. ${ }^{83}$ Seyyahın verdiği bilgilerden zaman içinde kalenin sahip olduğu eski fiziki koşullarını ve işlevini kaybettiği ve bakımsız bir durumda olduğu anlaşılmaktadır. Aslında Osmanlı Devleti, gerek fetih sırasında gerekse sonrasında adaya yönelecek olası saldırılara karşı bazı tedbirler almıştır. Bu doğrultuda adanın güçlü bir savunma çemberiyle korunması ve mali yapısının güçlendirilmesi için, Lefkoşa, Limasol, Mağusa, Baf ve Girne kalelerine 2279 adet topçu, gönüllü, müstahfız, azeb ile 1000 yeniçeri olmak üzere toplam 3779 asker yerleştirdiği bilinmektedir. ${ }^{84}$

Bunlara ek olarak, seyyah kentte dört hamam, bir zamanlar kilise olan sekiz cami, altı adet Rumlara ait şapel ve bir Katolik manastır ve artık yıkılmaya yüz tutmuş bir kervansaray olduğu bilgisini aktarır. Lefkoşa'nın geri kalan kısmının ise, pek çoğunun eski yapılardan kalma temellerin üzerinde tuğla ve topraktan inşa edilmiş evlerden oluştuğunu söyler. Kinneir, kentin çarşısı hakkında da bazı bilgiler verir. $O$, kentin çarşısını her taraftan yağmur alan, üzeri çatı yerine halılarla örtülü ancak içinde çeşitli malların bulunduğu bir yer olarak tasvir eder. ${ }^{85}$ Seyyahın verdiği bilgilerden, kentin çarşısının fiziki bakımdan olumsuz koşullara sahip olduğu, ancak buna rağmen zengin bir çarşı olduğu anlaşılmaktadır. Seyyah ayrıca Lefkoşa'ya üç kapıdan girildiğini ve bu kapıların Larnaka ${ }^{86}$, Cerina (Girne) ve Baf kapıları olduğunu söyledikten sonra, şehre giriş yapılan bu kapılar arasında Cerina (Girne) kapısının dikkate değer olduğunun altını çizer. Çünkü burası Rum manastırları ile doludur ve Olimpus Dağı'nın beyaz zirvesi buradan görülebilir. ${ }^{87}$ Kinneir'in, şehrin geçmişine ait yapılarla ilgili zengin bilgiler vermesine rağmen Osmanlı dönemi yapıları hakkında susması dikkate değerdir.

\footnotetext{
${ }^{82}$ Kinneir, a.g.e., s. 190.

${ }^{83}$ Kinneir, a.g.e., s.190.

${ }^{84}$ Çiçek, "Kıbris", D.I.I.A., C.25. 2002, s.374.

${ }^{85}$ Kinneir, a.g.e., s.191.

${ }^{86} \mathrm{Bu}$ kapının ismi aslında Mağusa kapısıdır; ancak seyyah yanlışlıkla, Larnaka yazmıştır. Zira kentte Mağusa Kapısı (Porte Giuliano), Girne Kapısı (Porta del Proveditore), Baf Kapısı (Porte Domenico) olmak üzere üç kapı bulunmaktadır bkz.Bener Hakkı Hakeri, "Lefkoşa Kenti, Surları ve Burçları", Kıbrıs Türk Ansiklopedisi, C.II. Kıbrıs Gazetesi Yayınları, ss. $240-241$.

${ }^{87}$ Kinneir, a.g.e., s.191.
} 


\section{F.Ü. Sosyal Bilimler Dergisi 2019-29/1}

Kinneir fiziki yapı hakkında bilgi verdikten sonra Lefkoşa'nın nüfusunu ele alır. O, kentin nüfusuna dair bilgileri, piskopostan aldığını belirtir. Bu bilgilere göre, kentte 2.000 Müslüman, bunun yarısı kadar Rum, 40 Ermeni ve 12 kadar Katolik Maruni ${ }^{88}$ aile yaşamaktadır. ${ }^{89} \mathrm{Bu}$ verilere bakılırsa, kentte Müslüman aile sayısının Rum aile sayısından iki kat daha fazla olduğu söylenebilir. Çevikel, adada 1750-1800 yılları arasında nüfusun ada genelindeki dağılımına ilişkin bazı tespitler yapar. Ona göre, zimmî nüfus daha çok Mağusa, Mesariye, Leymosun, Piskobi, Baf ve Kukla' da ${ }^{90}$ yoğunlaşmaktadır. Ayrıca Lefkoşa, Gerine, Tuzla, Hırsofi, Gilan, Evdim ve Değirmenlik gibi yerlerde gayrimüslim nüfus adı geçen yerlere nazaran fazla yoğun değildir ve bu yerlerde Türk nüfus daha yoğundur. Çevikel, bu tespitini, zimmîlerin en az bulundukları yerin Lefkoşa ve en yoğun bulundukları yerin ise Mesariya olmasına dayandırır. Buna ek olarak, adanın merkezi konumunda olan Lefkoşa ve civarının Türklerin en yoğun bulundukları yerler olduğunu söyler ve belki de bu nedenle, Şer'iye sicillerinde Türklerle ilgili kayıtların çoğunun Lefkoşa kazasına ait olduğuna vurgu yapar. Örneğin, adada 1750-1800 yılları arasında kayıtlara yansıyan 12 boşanma olayından ikisinin de Mağusa ve Tuzla Merkez mahallelerinde gerçekleşmesinden yola çıkarak, Türklerin büyük bir olasılıkla bu kazalarda çoğunlukla merkezde, yani kale içlerinde ikamet etmiş olduklarını söyler. ${ }^{91}$ Bu bağlamda, Çiçek 1698-1726 yıllarına ait Şer'iye sicillerine göre, Arap Ahmed Paşa, Kale Ardı, Çatalhurma, Abdi Çavuş, Ömeriye, Tahte'l-kale, Tophane ve Kızılkule gibi mahallerin Lefkoşa'da kurulmuş ve Türklerin çoğunluk teşkil ettiği kimi mahalleler olduğunu belirtir. ${ }^{92}$ Aynı zamanda, adaya gelen seyyahların verdiği bilgilerden hareketle, aslında 16. yüzyılın sonlarında Lefkoşa, Mağusa, Girne ve Baf gibi şehirlerin önemli ölçüde Türkleştiğinden söz eder. ${ }^{93}$

Özkul ise, 1726-1750 yılları arasını kapsayan ada üzerine yaptığı çalışmada, Lefkoşa kaza merkezinde 38 mahallenin tespit edildiğini ve ada halkının din ve inanç kimliklerine göre ayrı mahallelerde yaşadıkları yönünde bazı görüşler olmasına rağmen, en azından Lefkoşa mahallerinde Kıbrıslıların karışık bir şekilde yaşadıklarının bilindiğini söyler. Buna ek olarak, Lefkoşa'da Baş, Kafesli, Çatal Hurma, Aya Keşano, Aya Luka, Aya Sava, Çakmaklı ve Manastır olmak üzere 8 mahallede Ortodoks zimmilerin çoğunluk olduğunu belirtir. Buna gerekçe olarak ise, Ortodoks zimmilerin oluşturduğu kethüdaların, mahallede yaşayanlar adına Ortodoks başpiskoposa kefil olmalarını gösterir. Fakat bunun adı geçen mahallelerde tamamen gayrimüslimlerin yaşadığı ve hiç Müslüman yaşamadığı anlamına gelmediğinin altını çizer. Örneğin, yukarıda adı geçen Baş mahallesinde Müslümanların da yaşadığına dair bazı hükümler bulunduğundan söz eder. ${ }^{94}$

\footnotetext{
${ }^{88}$ Çevikel, Jennings'in 17. yüzyılın ilk yarısında Kıbrıs’ta Marunî denilen bir topluluğun da bulunduğuna dair fazla bilgi içermeyen birkaç kayda rastladığını belirtir bkz. Nuri Çevikel, "Osmanlı Kıbrıs'ında Müslim-Gayrimüslim İlişkileri ve İhtida meselesi (1746-1801)", Atatürk Kültür Dil ve Tarih Yüksek Kurumu, C.II, Tarih ve Medeniyetler Tarihi, Ankara: Atatürk Kültür Dil ve Tarih Yüksek Kurumu 2012, s.942.

${ }^{89}$ Kinneir, a.g.e., s. 190.

${ }^{90}$ Örneğin, Balta tarafından İngilizce olarak kaleme alınan bir çalışmada 1831 yılında Baf-Kukla'da 1.462 Müslüman ve 2.271 gayrimüslim olmak üzere toplam 3.733 kişinin vergiye tabi olduğu belirtilmektedir bkz. Evangalia Balta- Mustafa Oğuz- Ali Efdal Özkul, Kouklia in Nineteenth Century Cyprus on the Ruins of a once Glorious Paphos, (ed.) Evangalia Balta, İstanbul: ISIS Press 2015, s.24.

${ }^{91}$ Çevikel, a.g.m., s.942-943. Ayrıca Çevikel, kaza ve nahiye merkezlerindeki mahallelerin bir kısmında bazen bir cemaatin, bazen de diğer bir kısmında başka bir cemaatin yoğun olduğunu belirtir. Ona göre, ada merkezi olan Lefkoşa'da aralarında Çatal Hurma, Manastır, Aya Kaşano, Aya Sava, Baş, Çakmaklı, Ermeni, Aya Luka, Kafesli Kenisa gibi toplam 25 mahalleden 9'unda zimmîler nüfus bakımından daha yoğunluktaydılar. Bunların çoğunda az da olsa Müslümanların yaşadığına dair de bazı kayıtlar bulunmaktadır. bkz. Çevikel, a.g.m., s.943. Çevikel çalışmasında 25 mahalleyi şu şekilde sıralar: Debbâğhâne, Câmî'-i cedîd, Ömeriyye, Karamânîzâde, İbrahim Paşa, Arab Ahmed Paşa, Mahmud Paşa, Çatalhurma, Manastır, Aya Kaşano, Abu Kavuk, Ayasofya, Tahte'l-kal'a, Aya Sava, Baş, Abdi Çavuş, Karaboya, Korkud Efendi, Çakmaklı, Nevbethâne, Ermeni, Aya Luka, Kızılkule, Kafesli Knisa, Tophâne bkz. Nuri Çevikel, Kıbrıs Eyaleti: Yönetim, Kilise, Ayan ve Halk (1750-1800) Bir Değişim Döneminin Anatomisi, Gazimağusa: Doğu Akdeniz Üniversitesi Basımevi 2000.

${ }^{92}$ Kemal Çiçek, Zimmis (Non-muslims) of Cyprus in the Sharia Court, 1110/39 A.H./1698/1726 A. D.,Unpublished Ph.D Thesis, Birmingham: University of Birmingham 1992, s.228.

${ }^{93}$ Çiçek, "Kıbrıs", s.377.

94 Özkul, a.g.e., s.210-211.
} 
Kinneir'in adayı ziyaretinde sonra 1831 yılında yapılan ilk nüfus sayımı verilerine göre ise, Kıbrıs'ta 15.585 Müslüman ile 29.780 gayrimüslim yaşamaktadır. Fakat Lefkoşa ve Mağusa sayıma dâhil edilmediğinden adanın toplam nüfusuna dair kesin rakamlar vermek güçleşmektedir. Ancak bazı çalışmalarda 1831 yılında Lefkoşa kazası hariç olmak üzere adanın her tarafında gayrimüslimlerin çoğunlukta olduğu yönünde bazı görüşler bulunmaktadır. ${ }^{95} \mathrm{Bu}$ görüşün, aynı zamanda seyyahın kentte Müslümanların nüfusunun Rumların nüfusunun iki katı olduğu yönünde verdiği bilgiyi de teyit ettiği söylenebilir.

Seyyahın verdiği bilgilere bakılırsa, adada zaman içinde yaşanan birtakım sorunlar neticesinde, özellikle Rumlar açısından yönetimin kötüye gittiği ve bu anlamda kimi sorunlar yaşandığı anlaşılmaktadır. Ayrıca seyyahın özellikle Kıbrıs'taki yönetim anlayışını diğer Osmanlı topraklarındaki yönetim anlayışından daha kötü ve despot olarak nitelemesi dikkat çekicidir. Kinneir, adada yaşayan tek çalışkan millet olan Rum köylülerin, gerek kötü ve adil olmayan Türk yönetimi gerekse Hıristiyan din adamlarının baskıları altında ezildiklerini ve bu baskıdan kurtulmak için adadan göç etmek için her firsatı kullanmaya çalıştıklarını belirtir. ${ }^{96}$ Hatta adadaki yöneticinin ve başpiskoposun özellikle adada meskûn olan insanların emekleri ile yıl boyunca ürettikleri mısıra el koyduklarını ve bu mısırı daha yüksek bir fiyatla ya ihraç ettiklerini yahut perakende olarak satarak haksız kazanç elde ettiklerinin altını çizer ${ }^{97}$ Seyyah bu din adamlarının adada sahip oldukları nüfuz hakkında bilgi vermeye devam ederek şöyle der:

“(..) Başpiskopos sahip olduğu zenginlik ve nüfus bakımından adada sözü geçen ikinci kişidir. Rum reayay ilgilendiren tüm meseleler onun yönetimi ve denetimi altındadır. Hatta adanın valisi Hristiyan reayadan vergi toplama işini son zamanlarda tüm yetkiyi kendinde toplayarak dragomana danışmak için tenezzül bile etmeyen bu piskopos vasıtasıyla yapar. Bu kişi kendini papaz yardımcılı̆̆ gibi daha alt bir görevde birtakım yollarla başpiskoposluk makamına yükseltmiştir. Çok büyük miktarlarda adadaki zengin insanlardan borç para almıştır. Bu paranın kendisine kredi açan insanlara geri ödenebilmesi ise ekonomik gücü olmayan fakir insanların sirtından sağlanmaya çalışılmuştır." 98

Görüldüğü gibi, seyyah adada, özellikle Hıristiyan reayanın maruz kaldığı kötü yönetimi ele almakta ve eleştirmektedir. Ancak aynı şeyi adada yaşayan Müslüman köylüler için yapmadığı dikkat çekmektedir. Zira seyyahın iddia ettiği gibi eğer Türk yönetiminden de kaynaklı sorunlar varsa, bunun sadece Hiristiyan reayayı etkilediği kadar Müslümanları da etkilemesi gerekir. Fakat seyyah adada bulunduğu süre zarfında yalnızca orada yaşayan Hıristiyanları ön plana çıkarma gayreti içinde olduğu ve onları adada ezilen ve mağdur edilen tek millet gibi gösterme çabası içinde bulunduğu göze çarpmaktadır.

Kinneir'in de da belirttiği üzere, ada nüfusunun zaman içinde azalmasının altında doğal ve beşeri nedenler kadar ${ }^{99}$ Osmanlı yönetiminin sert emirlerini içeren fermanlarla uyarılan yöneticilerin yanlış tutum ve davranışlarının da etkili olduğu söylenebilir. Bununla birlikte, kilise yöneticilerinin ve yönetici konumundaki kişilerin halktan usulsüz vergi almaları da adada bulunan nüfusun azalmasına ve dağılmasına yol açmıştır. ${ }^{100}$ Kinneir, buna benzer durumun İspanya Savaşı esnasında da yaşandığını, tüm mısırın Maltalı tüccarlar tarafından bu şekilde satın alındığını ve halkın günlük ekmek ihtiyacının karşılanması için gerekli olan miktarın bile ayrılmadığını belirtir. ${ }^{101}$ Adadaki yönetim şekli 18. yüzyılın sonunda patlak veren Osmanlı-Rus Savaşının yarattığı ekonomik sorunlar nedeniyle Ortodoks Rumların Osmanlı Devleti nezdinde temsilcileri olan başpiskopos ve dragomanın İstanbul'a gönderdiği heyetin talebi ile yeniden değiştirilmiştir. Bu yeni yönetim tarzı

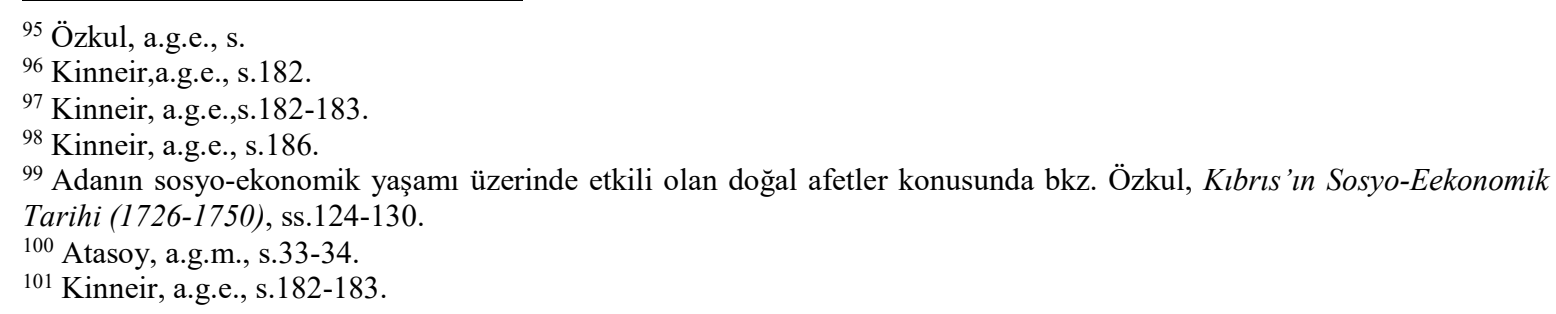




\section{F.Ü. Sosyal Bilimler Dergisi 2019-29/1}

piskoposların ve dragomanların nüfuzunun daha da artmasına sebebiyet vermiştir. ${ }^{102}$ Ayrıca başpiskoposların vergi toplama hak ve yetkileri daha da genişletilmiştir. Seyyahın ifadelerinden yola çıkılarak bu din adamlarının sahip oldukları nüfuzu kötüye kullanarak kendi tebaasına haksız angaryalar yükledikleri ve köylülerin bu angaryaların altında ezildikleri söylenebilir. Seyyahın verdiği bilgilerden, zaman zaman bu konudaki şikâyetler üzerine devlet tarafindan fermanlar yayınlanmasına rağmen, adadaki yönetim anlayışının reaya lehine değişmesi yönünde fazla bir şey yapılmadığı, hatta yapılan idari değişikliklerle bazı yöneticilerin daha da nüfuz kazanmalarının önünün açıldığı söylenebilir.

Kinneir, adanın askeri gücünün üç yüz kişiden oluştuğunu, disiplinsiz ve silahsız olan dört bin yeniçerinin ise adanın farklı yerlerinde olduğunu söyler. Bununla birlikte, seyyah adada söz sahibi olmasının hem Akdeniz'de hem de Levant'ta İngiltere'ye önemli bir güç kazandıracağını söyler. Ayrıca bunun gerçekleşmesi durumunda, İngiltere'nin Anadolu'da hem İstanbul hükümetini kontrol altında tutulabileceğini hem de Rusya'nın yayılmasının önünde bir engel teşkil edeceğinin altını çizer. ${ }^{103}$ Seyyahın verdiği bilgilerden, onun adada gerçek bulunma amacı da kendiliğinden ortaya çıkmaktadır. Onun siyasi ve ekonomik bakımdan ülkesinin çıkarlarını gözetmek ve bu doğrultuda adaya dair kimi bilgiler toplayarak rapor hazırladığı anlaşılmaktadır. Böylece adanın jeo-stratejik açıdan İngiltere için hayati bir işleve sahip olduğunun altını çizdiği görülmektedir. Benzer şekilde, Osmanlı ordusuna iltica eden ancak dinini değiştirmeyen Alman seyyah Murat Efendi de gezi notlarında benzer şekilde eski zamanlarda dokuz kral tarafından yönetilmiş olan Kıbrıs ile pek çok devletin yakından ilgilendiğini ve bu ilgiden ise vazgeçilemeyeceğinin açıça görüldüğünü belirtir. ${ }^{104}$

\section{Sonuç}

Kıbrıs günümüzde olduğu gibi tarihin en eski devirlerinden itibaren sahip olduğu jeopolitik ve jeo-stratejik konum itibariyle pek çok devletin hâkimiyet tesis etmek için birbirleri ile mücadele ettikleri bir yer olmuştur. Adanın sahip olduğu bu önem, Osmanlı Devleti'nin de dikkatini çekmiş ve bu nedenle Osmanlı Devleti birtakım siyasi, askeri ve ekonomik şartlarında etkisiyle Kıbrıs'1 1571'de kendi topraklarına katmıştır. Adanın fethini müteakip Osmanlı Devleti, orada sadece klasik Osmanlı idari düzeninin tesis edilmesi için gerekli olan adımlar atmamış aynı zamanda izlediği iskân politikasının gereği Anadolu'dan çoğunluğu Müslüman olan bir nüfusu da adaya yerleştirmiştir. Osmanlılar adaya hâkim oldukları ilk dönemlerde, Kıbrıs'ta yaşayan çeşitli etnik gruplar arasında denge gözeten, adalete ve hoşgörüye dayanan bir yönetim uygulamaya çalışmışlardır. Ancak seyyahın da yer yer değindiği gibi, Osmanlı Devleti'nin zaman içinde yaşadığı siyasi ve ekonomik gerilemeye paralel olarak diğer yerlerde gibi adada da bazı sorunlar baş göstermiş̧tir. 19 yüzyıl Osmanlı Devletinin her bakımdan derin değişim ve dönüşümden geçtiği istisnai bir dönem olmuştur. Özellikle anılan yüzyılda Osmanlı topraklarına gelen batılı seyyah ve araştırmacıların sayısında önemli bir artış olmuştur. Elbette bu nedensiz değildir. 19. yüzyılda özellikle İngiltere ve Fransa gibi batılı güçlerin Osmanlı topraklarında nüfuz sahibi olmalarını gerektiren önemli siyasi ve ekonomik menfaatleri bulunmaktaydı. Bu nedenle Kinneir örneğinde olduğu gibi, kendi ülkelerinin bazı kuruluşları tarafından finanse edilen kimi seyyah ve araştırmacılar Osmanlı topraklarına gelerek hemen her konuda bilgi toplamışlar ve kendi ülkelerinin çıkarlarına hizmet etmeye yönelmişlerdir.

Kıbrıs'a gelen bu seyyahlardan birisi de İngiliz asıllı olan Binbaşı John McDonald Kinneir'dir. 19. yüzyılın başında adada bulunan seyyahın o dönem adanın içinde bulunduğu fiziki, siyasi, idari, sosyal ve ekonomik yapıya dair bazı gözlem ve incelemelerde bulunduğu ve eserinde bu konuda önemli bilgiler verdiği söylenebilir. Ancak Kinneir'in kimi doğru bilgiler aktarmasına rağmen pek çok batılı seyyahın yaptığı gibi yer yer değerlendirmelerinde gelmiş olduğu kültürün ve dinin etkisi altında kalarak bazı şeylere ön yargılı yaklaştığı söylenebilir. Seyyahın, özellikle adanın fiziki yapısı hakkında bilgi verirken bu önyargılı tutumu daha açık hale gelir. Örneğin, onun, adada bulunduğu

\footnotetext{
${ }^{102}$ Çiçek, "Kıbrıs", s.375-376.

${ }^{103}$ Kinneir, a.g.e., s. 186.

${ }^{104}$ Murat Efendi, Türkiye Manzaraları, (çev.) Alev Sunata Kırım İstanbul: Kitap Yayınevi, 2007, s.149.
} 
esnada Mağusa, Larnaka ve Lefkoşa gibi şehirlerdeki Hıristiyan yapılar hakkında bilgi verirken Osmanlı dönemi yapılar hakkında, neredeyse hiç bilgi vermemesi dikkat çekicidir. Ayrıca seyyahın adadaki idari yapı ve yönetim anlayışı hakkında analiz yaparken de benzer bir tutum sergilediği dikkat çekmektedir. Bu bağlamda, adada yaşayan Hıristiyan halkı gerek Türk yönetimi gerekse Hıristiyan din görevlilerin kötü yönetimi altında ezilen mağdur bir topluluk olarak gösterirken, adada yaşayan Müslüman halkın yaşadığı sorunlar hakkında susması manidardır. Dolayısıyla onun örtük bir biçimde okuyucunun zihninde adada yaşayan Müslümanların hayatının Hıristiyan ahaliye nazaran daha iyi olduğu gibi bir imaj yaratmasına yol açabilecek şekilde bilgi aktardığı söylenebilir. Ancak Kinneir'in bu konularda verdiği önyargılı ve nesnel olmayan bakış açısı bir kenara bırakıldığında, Kıbrıs'ın özellikle coğrafi, fiziki ve sosyo-ekonomik yapısına dair verdiği bilgilerin, adanın 19. yüzyılın başında içinde bulunduğu durumu anlamamıza yardımcı olan önemli katkılar sağladığını belirtmek gerekir.

\section{KAYNAKÇA}

Akalın, Durmuş, Cemil Çelik (2012), “XIX. Yüzyllda Doğu Akdeniz'de İngiliz-Fransız Rekabeti”, Turkish Studies, Vol.7/3, ss.21-45.

Atasoy, Ahmet (2011), "Kuzey Kıbrıs Türk Cumhuriyetinin Nüfus Coğrafyası", Mustafa Kemal Üniversitesi Sosyal Bilimler Enstitüsü Dergisi, C.8, S.15, , ss.29-62.

Balta, Evangalia, Filiz Yaşar, Elif Bayraktar (2012), "Gayr-i Muslims in Tuzla (Larnaca): The Census Register of 1831", Histrories of Otttoman Larnaca, (ed. by) Evangalia Balta, Theoharis Stavrides, Ioannis Theocharides, İstanbul: ISIS Press, ss.140-244.

,Mustafa Oğuz- Ali Efdal Özkul (2015), Kouklia in Nineteenth Century Cyprus on the Ruins of a once Glorious Paphos, (ed.) Evangalia Balta, İstanbul: ISIS Press.

Burnaby, Fred (1877), On Horseback Through AsiaMinor, Vol.I, London: S. Low, Marston, Searle, \&Rivington, s.243.

Cobham, C. D. (1969), Excerpta Cypria: Materials for a History of Cyprus, Nicosia.

Çevikel, Nuri (2000), Kıbrls Eyaleti: Yönetim, Kilise, Ayan ve Halk (1750-1800)/Bir Değişim Döneminin Anatomisi. Gazimağusa: Doğu Akdeniz Üniversitesi Basımevi.

(2001), Klbrıs Akdeniz'de Bir Osmanlı Adası (1570 -1878), İstanbul: Tarih İnceleme Dizisi. (2006a), Kıbris'ta Osmanlı Mirası (1571-1960), İstanbul: 47 Numara Yayınc1l1k.

(2012), “Osmanlı Kıbrıs'ında Müslim-Gayrimüslim İlişkileri ve İhtida meselesi (1746-1801)”, Tarih ve Medeniyetler Tarihi, C.II, Ankara: Atatürk Kültür Dil ve Tarih Yüksek Kurumu, , ss.937-965.

Çiçek, Kemal (1992), Zimmis (Non-muslims) of Cyprus in the Sharia Court, 1110/39 A.H./1698/1726 A. D., Unpublished Ph.D Thesis, Birmingham: University of Birmingham.

( 2002), “Kıbris”, D.I.A., C.25, , ss.375-379.

( 2003), "Larnaka", D.İ,A., C.27, , ss.105-107.

Demirkent, Işın (2002), “Kıbrıs”, D.İ.A., C.25, , ss.371-374.

Emecen, Feridun (2001), Kıbrıs'ta İlk Osmanlı İdari Yapılanması, "Dünden Bugüne Kıbrıs Meselesi”, İstanbul: Tarih ve Tabiat Vakfi.

Erdoğru, M. Akif (1993), "Kıbrıs'ın Türkler Tarafindan Fethi ve İlk İskân Teşebbüsü", Kıbrıs'ın Dünü-Bugünü Uluslararası Sempozyumu, Ankara: KKTC Doğu Akdeniz Üniversitesi ve Van 100. Yıl Üniversitesi Rektörlükleri Yayınları.

Erdönmez, Celal (2004), Ser'iyye Sicillerine Göre Kıbris'ta Toplum Yaplsı (1839-1856), SDÜ Sosyal Bilimler Enstitüsü Tarih Anabilim Dalı, Yayınlanmamış Doktora Tezi, Isparta.

Gökçe, Turan (1997), “1572 Yııında İç-İl Sancağından Sürülüp Kıbrıs’ta İskân Edilen Aileler”, Türk Dünyası Incelemeleri Dergisi, ss.1-78.

Hakeri, Bener Hakkı (1993), Başlangıçtan 1878'e dek Kıbrıs Tarihi, Lefkoşa: Milli Eğitim ve Kültür Bakanlı̆̆ı Yayını.

(1992), "Lefkoşa Kenti, Surları ve Burçları", Kıbrıs Türk Ansiklopedisi, C.II, Kıbrıs Gazetesi Yayınları, ss.240-241. 


\section{F.Ü. Sosyal Bilimler Dergisi 2019-29/1}

Halaçoğlu, Yusuf (2001), “Osmanlı Döneminde Kıbrıs'ta İskân Politikası”, Dünden Bugüne Kıbrıs Meselesi, (yay. haz.) Ali Ahmetbeyoğlu-Erhan Afyoncu, İstanbul: TATAV Yayınları, ss.39-46.

İmer, Zahide (2005), "Miladi Dönem Öncesi Orta Asya'da İpek”, Bilig, S. 32, ss.1-32.

Kinneir, Jonh McDonald (1818), Journey Through Asia Minor, Armenia and Koordistan in the years 1813and 1814, London: John Murray.

Köse, Muhammed (2016),“Arşiv Belgelerine Göre XIX. Yüzyılda Kıbrıs Ceziresi Tuzla/Larnaka’nın Demografik Yapısı”, Osmanlı Döneminde Kıbrıs, İstanbul: Seçil ofset, ss.294-303.

Maier, F. G. (1968), Cyprus: From Earliest Time to the Present Day, (trans. from German by) Peter Gorge, London: Elek Books.

Makhairas, L. (1932), Recital concerning the Sweet Land of Cyprus (1458), (ed. and trans. by) R.M. Dawkins, Vol.I, Oxford: Clarendon Press.

Mariti,G. (1971), Travels in the Island of Cyprus, First published in Lucca in 1769 as "Viaggiper L'Isoladi Cipro", (translated from the Italian by) Claude Deleval Cobham, Unchanged Reprint of the Edition London 1909, London; Zeno.

Murat Efendi (2007), Türkiye Manzaraları, (çev.) Alev Sunata Kırım İstanbul: Kitap Yayınevi.

Orhonlu, Cengiz (1971), “Osmanlı Türklerinin Kıbrıs adasına Yerleşmesi (1570-1580), Milletlerarası Birinci Kıbrls Tetkikleri Kongresi (14-19 Nisan 1969), Türk Heyeti Tebliğleri, Ankara: Türk Kültürünü Araştırma Enstitüsü Yayınları, ss. 91-97.

Osmanlı idaresinde Kıbrıs (2000), (yay. haz.) Hacı Osman Yıldırım, Ankara: Devlet Arşivleri Genel Müdürlüğü.

Öğün, Gülay (2001), "Kıbrıs'ta İslam Hâkimiyeti ve Selçuklular Zamanında Kıbrıs İle Ticaret İlişkileri", Dünden Bugüne Kıbris Meselesi, (yay. haz.) Ali Ahmetbeyoğlu-Erhan Afyoncu, İstanbul.

Özkul, Ali Efdal (2010), Kıbrıs'ın Sosyo- Ekonomik Tarihi (1726-1750), İstanbul: Dipnot Yayınevi. (2012), “Osmanlı Kıbrıs'ında İpek Üretimi ve Ticareti”, Tarih ve Medeniyetler Tarihi, C.V, Ankara: Atatürk Kültür Dil ve Tarih Yüksek Kurumu, ss. 2395-2409.

(2013), "The Consuls and Their Activities in Cyprus Under the Ottoman Administration (1571-1878)", Turkish Studies, Vol. 8/2, ss. 239-283.

(2014), “Osmanlı İdaresinde Kıbrıs’ta Ermeni Toplumu ve Faaliyetleri”, Yeni Türkiye, S.60, ss.1-42.

(2014), "Silk Production and Trade in Ottoman Cyprus", Studies on Ottoman Cyprus, Festschrift in Honor of Ioannis P. Theocharides, (ed. by) E. Balta, G. Salakidis, T. Stavrides, İstanbul, ss. 170-210.

Panzac, Daniel (1997), Osmanlı Imparatorluğu'nda Veba (1700-1850), (çev.) Serap Yılmaz, İstanbul: Tarih Vakfi Yurt Yayınları.

Osmanlı idaresinde Kıbrıs: Nüfusu-Arazi Dağıllmı ve Türk Vakıfları (2000), (ed) Yusuf Sarınay, Ankara: T.C. Başbakanlık Devlet Arşivleri Genel Müdürlüğü, Osmanlı Arşivi Daire Başkanlığı.

Tarkan, M. Tevfik (1975), Kıbrıs (Genel Çizgileriyle), Ankara: Atatürk Üniversitesi Edebiyat Fakültesi Yayınları.

Tavernier Seyahatnamesi (2006), (çev.)Teoman Tunçdoğan, İstanbul Kitap Yayınevi.

Tozer, Henry Fanshawe (1881), Turkish Armenia and EaternAsia Minor, London: Longman, Green and Co.

Turan, Şerafettin (2003), "Levant”,D,I.I., C.27, İstanbul, ss.145-147.

Uluca, Ege (2006), Gazimağusa Kaleiçi’nin Tarihsel Süreç İçindeki Kentsel Gelişsimi Ve Değişimi, İstanbul Teknik Üniversitesi Fen Bilimleri Enstitüsü, Yayınlanmamış Doktora Tezi, İstanbul.

Yılmaz, Özgür (2006), Batıll Seyyahlara Göre Trabzon (1808-1878), Karadeniz Teknik Üniversitesi, Sosyal Bilimler Enstitüsü Tarih Ana bilim Dalı, Basılmamış Yüksek Lisans Tezi, Trabzon.

Yuvalı, Abdulkadir (1993), "Selçuklular Döneminde Kıbrıs'ın Anadolu İle Siyasi ve Ticari ilişsileri", Kıbrıs'ın Dünӥ-Bugünü Uluslararası Sempozyumu, Ankara, ss.35-41. 